\title{
Problems in Applying the Treaties: Ambassadors and Envoys
}

After the treaties initiated a period of peaceful relations and newly strengthened bilateral agreements, commercial exchanges increased and larger numbers of Muslims began to arrive in the Iberian Peninsula. As we shall see in the following chapters, ambassadors, special envoys, ships' captains, sailors, merchants, exiles, travelers, converts, and adventurers visited Spanish territory, sometimes remaining for long periods and even dying there.

We shall speak first of the ambassadors, envoys, and ships' captains (arraeces). ${ }^{1}$ Spanish authorities actually created every possible delay and obstacle to their attempts to reach the monarchy's domains. The Secretariat of State sent a stream of instructions along those lines to its various consuls general who served in the Maghreb. There were two principal reasons for this policy. The first was to avoid unpleasant incidents during the ambassadors' sojourns in Spain: it was essential to preserve Hispano-Muslim understanding in general and Hispano-Moroccan amity in particular. The second was the heavy drain that the embassies made on the royal treasury, ${ }^{2}$ making it desirable to reduce their visits to the Spanish court to a minimum. ${ }^{3}$ Likewise the authorities strove

1 I include the arraeces who headed embassies and came as delegates from the sultan and his circle. In this chapter I will discuss them as such, though their mission is not always precisely known. The next chapter will deal with those who simply arrived as captains of warships.

2 The situation in France was similar: "The Ministry and consuls tried to avoid missions by Maghrebi envoys in France. This attitude cannot be explained entirely by financial considerations, that is, by the wish to avoid the need to pay the envoys and assume the other expenses that a mission from Barbary incurred. The motive, in reality, was to control communications and channel them through the consuls. For the same reason, ministry and consuls agreed in refusing to recognize the Bey's reciprocal right to install a consul in Marseille" ("Ministère et consuls essayaient d'éviter les missions d'envoyés maghrébins en France. Cette attitude ne s'explique pas uniquemente par des considérations d'ordre financier, c'est-à-dire par la volonté d'éviter la nécessité de défrayer les envoyés et d'assumer les autres dépenses qu'entraînait une mission barbaresque. Il s'agissait en effet de contrôler les communications et de les canaliser à travers les consuls. Pour la même raison, ministère et consuls étaient d'accord sur le refus de reconnaître le droit de réciprocité du bey d'installer un cónsul à Marseille"): Windler, $L a$ diplomatie, 163. For the Turkish case see Mehmed Effendi, Le paradis, 28-30.

3 These hesitations applied even to the embassy by Muhammad Ibn Utman al-Miknasi in 1789. A draft letter from the Secretariat of State to Count O'Reilly, military governor of Cádiz, expresses doubts about the ambassador's status and recommends reducing the expenses of 
to send as few delegations as possible to the Maghrebi countries and the Levant, reserving them for times when there was a genuine need to maintain good relations.

Only a few Muslim ambassadors were sent to the Spanish court: aside from al-Gazzal, they were his fellow Moroccan Muhammad Ibn Utman and the Turk Ahmet Vasif Effendi. The two Moroccans were not problematic: they fulfilled the duties of their office and were received with the proper respect in Spain. Ahmet Vassif Effendi, however, adopted a harsh attitude, though the difficulties he presented were not grave ones.

A much larger group were the ambassadors, chiefly Moroccans, who paused in Spanish cities or ports on their way to or from their destinations in other countries. And more still were North African envoys or delegates, most of whom were sent by their sovereigns to purchase specific merchandise.

Some of these ambassadors, envoys, and captains in transit became involved in incidents that, while not really serious, illustrate the nature of HispanoMoroccan relations. We will understand the cases better if we remember our discussion from Chapter 5 , especially of the exchange of gifts and counter-gifts. The sultan of Morocco granted broad privileges to Spaniards (as subjects of the Spanish monarch) believing that they ought to reciprocate with requested services and favors (called in Spanish diplomatic correspondence finezas, "delicate attentions"). As a strategy, he tended to offer a country - Spain, in this case - favorable conditions for trade that actually lessened his own intake of customs duties. An extreme example was his giving Spain the monopoly on the export of wheat from Dar al-Beida (Casablanca), as well as various licenses to export amounts of wheat without paying duty on them. The Secretary of State and the Spanish consul in Morocco, aware of the sultan's thinking, provided some of the services and products he demanded directly, or had them paid for by commercial firms like Patrón and its partners or the Five Guilds (Cinco

his visit as far as possible: "Although the King of Morocco has told the King [of Spain] that he has given the aforementioned Moor the rank of Ambassador, he may not actually hold it, and [the king] may have used the name of Ambassador as a generic description; for Moroccans, unlike Europeans, do not make such a specific distinction among the different titles for public Ministers" ("Aunque el Rey de Marruecos ha avisado al Rey que ha dado el carácter de Embaxador al mencionado Moro, es posible que no le tenga, y se haya servido del nombre de Embaxador como de una denominación genérica, pues no hazen los Marroquíes tan especifica distincion, como los Europeos, de las diversas representaciones de los Ministros publicos"). O'Reilly is told to organize the envoy's journey to Madrid while keeping costs to a minimum, although not to "depart from what decency demands": to Count O'Reilly, 26 October 1779, AHN, Estado, Leg. 5819. 
Gremios Mayores) of Madrid, which held the monopoly on exporting wheat from Dar al-Beida. ${ }^{4}$

It is important to know that administrative posts in the Moroccan state were usually unpaid; their holders were expected to profit in the course of carrying out their duties. Naturally this situation created problems, especially when the sultan sent his trusted secretaries, alcaides, and captains to negotiate in Spanish ports. He expected Spain (or any other country involved) to finance their missions: to charter the ship, provide board and lodging, etc. Sometimes the envoys were not carrying enough ready cash to purchase what the sultan had ordered. When Moroccan corsair ships or warships docked in Spanish ports they assumed they would be issued water and food, or have their vessels repaired at Spain's expense. The Muslim delegates expected that a Spaniard in authority such as the consul in Tangier, the governor of Cádiz, the Secretary of State, or a local official would fulfill the sultan's requests without further payment.

There were many cases of abuses by ambassadors and envoys. They took advantage of the expectations inherent in the gift/counter-gift exchange - with its built-in time lag - and of the "rights of man" described in the previous chapter. Ethnic and cultural differences also played a role, though not a decisive one. In many such cases the Muslims claimed ignorance of local Spanish laws and customs in order to avoid paying for services, customs duties, and debts. In the following sections we shall recount some of these cases in detail. It did not help matters when some of the sultan's envoys demanded deference at a higher rank than the one they held, for which they were accused of lacking in scruples. ${ }^{5}$

Spaniards realized what was happening, but usually preferred to pay the price so as to continue enjoying the privileges that the sultan granted them in Morocco. The incidents I have identified are largely similar and can be said to follow the same pattern.

Still, these practices created unease among authorities such as the Secretary of State and in the ports frequented by Moroccan envoys and captains. The court ordered officials in Cádiz, Cartagena, Málaga, and other cities to provide the minimum assistance necessary and have the ships depart as quickly as possible, fearing that disagreements might imperil the good relations between the two states.

4 Rodríguez Casado, La política marroquí, 354-59; Lourido Díaz, "El comercio del trigo."

5 Some scholars, to explain the frequent incidents and justify the Spanish monarchy's mistrust, maintain that the Moroccan ambassadors and envoys were poorly chosen: Martínez, "El Tratado de Paz de 1767." But the main cause of the incidents appears to lie elsewhere. 
In all the cases we study it is clear that everyone in the Spanish government - Secretaries of State, governors of cities and regions, and consuls general - did not want incidents involving ambassadors, envoys, captains, and Moroccan notables to disturb the friendly relations that existed between Spain and Morocco in particular, and Spain and the Muslim world in general. The authorities tended to tolerate the exaggerated demands of some envoys, while at the same time trying to prevent complaints about those individuals from reaching the ears of the sultan, who would have meted out severe punishment. It was hoped that the guilty parties would then look more favorably on Spain's policy toward Morocco. In fact the opposite effect could occur: knowledge that certain Moroccan envoys enjoyed an indulgence they did not deserve created an incentive for further bad behavior. The number of incidents was not large, however, at least according to the documents at our disposal. SpanishMoroccan relations in particular, and Spanish-Maghrebi ones in general, must not have been as complicated and full of friction as histories of the period have assumed.

\subsection{Muslim Ambassadors at the Spanish Court}

Only one figure really interests us here: Muhammad Ibn Utman, who led missions to Spain in 1780 and 1791-1792. But we also consider Muhammad alDalimi, sent in 1792 by Mulay Hisam while he was contesting the throne of Sultan Muley Yazid, and Vasif Effendi, who arrived in 1787. Other envoys, as mentioned above, merely stopped in Spain in the course of their travels to various European countries or the Ottoman Levant.

\subsubsection{Muhammad Ibn Utman of Morocco (1780 and 1791)}

Muhammad Ibn Utman was, without a doubt, the Moroccan politician most respected by the Spanish authorities in the last third of the eighteenth century. Several studies have been published on his political activity in Morocco and his diplomatic missions to Europe and the Ottoman Empire. ${ }^{6}$

A son of the pasha of Taroudant, Ibn Utman learned basic Spanish from Franciscan friars and Spanish slaves. He formed a friendship with Jorge Patissiati, who was interim consul general in 1767 and later Spain's vice consul in Tangier; he was also acquainted with Francisco Pacheco, another Spanish

6 Between 1781 and 1785 he served as his country's ambassador to Malta, Naples, and the Ottoman Empire: Freller, “'The Shining on the Moon' ”; Arribas Palau, "Rescate de cautivos musulmanes en Malta" and "Muhammad ibn Utman designado gobernador." 
vice consul, and with Father Boltas of the Catholic mission in Meknes. In 1779 the Moroccan emperor called him his "faithful and esteemed secretary."7 The Polish writer Jean Potocki, who saw him often in Madrid, considered him "one of the wisest men that Mohammedanism has produced, and the only one of whom I have heard nothing but praise from his countrymen." ${ }^{8}$

Ibn Utman's first embassy to Spain, in 1779-1780, had the aim of negotiating the Convenio or agreement signed in that year that ratified and completed the terms of the Treaty of Peace of 1767 , while ending the crisis provoked by the war of $1774-1775$. He was also charged with freeing the largest possible number of Muslim slaves.

He disembarked at Cádiz in December 1779 with a retinue of twenty-six persons that included Sidi Mohamed Buinat, who had held high posts in the Moroccan army; Talbe Cali, of Turkish origin, an adviser to the ambassador on the strength of his broad political experience ("he assures us that he has been in the service of the King of Morocco for many years"); and Layse el Suet acting as interpreter ("who, they say, is the same one who accompanied al-Gazzal"). Another member may have been Ali Biris. The delegation brought six Maltese captives who were to be granted their freedom by the king of Spain. ${ }^{9}$ During a three-day stay in Cádiz the party visited places of interest and viewed dramatic performances staged in their honor. On 23 December the embassy arrived in Seville in five carriages, two buggies, and a wagon, was housed in the Alcázar, and later departed for Córdoba.

After the Moroccans' arrival in Madrid on 12 January 1780, negotiations began on the articles of the proposed agreement. Their Spanish interlocutor was the Secretary of State, Count Floridablanca. The document, in Arabic and Spanish, was signed on 30 May in Aranjuez, and Ibn Utman was able to visit El Escorial and La Granja.

The ambassador began his homeward journey in early June, stopping for two days in Toledo. In Villarrobledo most of the population came out to greet him, a festival was organized, and chocolate and sweets were served; Albacete provided a similar welcome. There was a dance in his honor in La Gineta, and another one evening in a convent of nuns in Elche. During a three-day visit to

7 Rodríguez Casado, "Apuntes para una biografía."

8 Potocki, Viaje al Imperio de Marruecos, 11.

9 The governor of Ceuta reported that the entourage included, beside those named, "twelve servants and six captive Maltese": Domingo de Salzedo, military governor of Ceuta, to Count Floridablanca, Ceuta, 13 November 1779. The Count of Xerena, governor of Cádiz, informed the Secretariat of State on 19 November 1779 that the group was made up of twenty-six persons: AHN, Estado, Leg. $5^{819}$. 
Murcia Ibn Utman visited factories where silk and gunpowder were made as well as public areas of the city; he also bought the freedom of two captive Muslim women for one hundred pesos. At a dance, the ambassador observed that "you might find a man sitting down while his wife or daughter danced with a stranger." In Cartagena, where he was also warmly welcomed, he visited the captives in the arsenal and distributed ten quintales of silver coins sent by the sultan of Morocco. ${ }^{10}$ As a kind of gift Charles II offered the sultan about thirty Algerian, Tunisian, and Turkish captives, and Utman obtained the freedom of twenty or twenty-five more who were too old or ill to serve; to these he was able to add fifty-five more whom he identified as Moroccan. In all, 113 freed slaves embarked in the Neapolitan brigantine El Rey de las Dos Sicilias under Captain Francisco Xavier Pillastro, which sailed on 10 July and arrived in Ceuta three days later. The group had been sent off with a month's supply of food.

In the meantime Ibn Utman left Cartagena by land, making a stop in Fuente Álamo where the governor's daughters performed music for him. He was welcomed in Totana and Lorca as well; in the latter town he declined an invitation to spend the night, but was delayed while the women sang and danced in his honor. Reaching Granada on 16 July he remained there for several days, then went on to Jerez for another two.

He embarked from the port of Tarifa on 1 August and reached Ceuta at 11 in the morning of the same day. After more than a month there he set out again, bearing letters with instructions from the sultan, on 6 September. Charles III wrote to Muhammad Ben Abdallah praising his ambassador:

Finally, I must tell you that your ambassador, since his arrival in Spain and especially at my court, has displayed such sensible, virtuous, and frank personal conduct, in his own household and in service to his mission, that he has proved worthy of my favor; and he deserves to remain in your good graces, which he had already earned when you named him to such an honored post. ${ }^{11}$

10 Cartagena's city council records show that he arrived in the city on 19 June and was received with the ceremony appropriate to his rank. He visited the Muslim captives, gave them financial aid, and asked that every Moroccan held in the arsenal be turned over to him: Martínez Rizo, Fechas y fechos, 262. Ibn Utman specified that the funds he brought should be "distributed among the Moors who are captives in Spain": Domingo de Salzedo, military governor of Ceuta, to Count Floridablanca, Ceuta, 13 November 1779: AHN, Estado, Leg. 5819 .

11 "Debo deciros, por fin, que Vuestro Embaxador ha observado desde su arribo a España, y singularmente en mi Corte, una conducta tan cuerda, virtuosa y franca en su persona, en su casa y en el servicio de su ministerio, que se ha hecho digno de mi favor y merece que 
These cannot have been empty words. The Secretariat of State wrote to José Boltas, head of the Catholic mission in Meknes, that "Al Talbe Ben-Otoman met and addressed the king with the greatest respect, praise, and generosity, and has shown every merit in his fine qualities, probity, and talent."12 The priest answered confirming that the sultan was very pleased with

the great deference that his envoy Ben-Otman offered to our Catholic king and all his royal family. Since he received the letters from his minister, [the sultan] has not ceased to praise and applaud the fine qualities of his friend Charles (this is his style) and to think of the great love that he has always felt for him. ${ }^{13}$

Ibn Utman's second mission to Spain began in late 1791 and continued into 1792. It seems that King Charles IV himself had sought him as a mediator after al-Yazid had attacked Ceuta and relations between Morocco and Spain had deteriorated. Ibn Utman reached Ceuta on 20 December 1791 with a retinue of fifteen that included a secretary, an interpreter, stewards, servers, cooks, musicians, and three slaves. They sailed on 23 December on the frigate Soledad, reached Cartagena four days later, and set out for Madrid on 3 January. The ambassador's charge was to avoid a declaration of war between Spain and Morocco, whose relations had suffered enormously after Muhammad Ben Abdallah died and his son Muley al-Yazid succeeded him. The new sultan also had to defend his throne against his brothers.

In spite of Ibn Utman's excellent relations with the Spanish court, and his many efforts during this unexpectedly long stay in Spain, his peace mission was unsuccessful. He left Madrid for Cádiz on 18 August and the next day Charles IV declared war on Muley al-Yazid. Messengers sent after the ambassador found him in Ocaña, and he was urged to stay there for fear the sultan would blame

vos le continuéis el que ya lograba cuando le nombrasteis para tan honroso cargo": Arribas Palau, "El paso de un embajador"; Elamri, "The Elixir for the Redemption of Captives"; Bokbot, "El Sultán Mohamed III y su embajador"; Torres-Fontes Suárez, Viajes de extranjeros, esp. the section "M.B. Utman al Miknasi. Al-Iksir fi fakak al asir," 515-30; Rodríguez Casado, La política marroquí, esp. Chap. 3, "La Embajada de Sidi Mohamed Ben Otoman y el convenio de 1780," 285-306.

12 Letter from the palace of El Pardo to José Boltas, 20 March 1780: AHN, Estado, 4313.

13 “.... L L os distinguidos honores, que ha debido su embiado Ben-Otman a Nuestro Catholico Rey, y toda su Familia Real. Desde que recibió las cartas de su dicho Ministro no ha cessado de elogiar y aplaudir las bellas prendas de su amigo Carlos (este es su estylo) y ponderar el grande amor, que siempre le ha tenido": José Boltas to Count Floridablanca, Marrakesh, 26 March 1780. 
him for not preventing the declaration. Not only had he lost the sultan's confidence, but it was rumored that he had converted to Christianity. Remaining behind in Ocaña with five members of his retinue, he sent the others on to Cádiz to take ship for Morocco; as the war dragged on he was invited back to Madrid in October, though as a private citizen and not an ambassador. He received an allowance and was visited regularly by a doctor. Finally on 4 April of the following year, when word reached Madrid of Muley al-Yazid's death, Ibn Utman left for Cádiz and embarked for Tetouan on 7 May. ${ }^{14}$

Spanish authorities praised Ibn Utman for his humanity, well demonstrated by his intercessions for two Spaniards condemned to die in Spain. As he passed through Cádiz in December 1779, the father of a soldier condemned to death for desertion pleaded with him to help save his son's life; he did so, and the son's sentence was commuted to ten years' service in a North African presidio. A few months later, in Cartagena, he interceded in the case of another condemned man, an hidalgo and silversmith who, after ten years in prison, was to be garroted for minting false coins. After the accused wrote to Ibn Utman the ambassador pleaded the man's case and achieved the same commutation as before. $^{15}$

The Moroccan envoy always favored Spain over England: he influenced the expulsion of the English from Tangier in 1780 during the war between the two countries. He also facilitated the concession to the firm of Campana, Patrón and Rizo of exclusive rights to export wheat from Dar al-Beida. ${ }^{16}$

Like al-Gassani and al-Gazzal before him, Ibn Utman met individuals who claimed to descend from the Muslims of Spain. In Bailén, he recalled, "the governor's representative and his sister approached us; their told us of their ancestry and said they descended from Muslims."17 He saw traces of the Muslims in the Andalusian countryside ("the imprint of the past is obvious here") and in Córdoba and Toledo, cities that he thought remained the same as when "the Muslims lived in them."18 He viewed with emotion the Islamic monuments of Córdoba, where he stayed several days; in the Alcázar of Seville he showed keen interest in its ornamental Arabic inscriptions; he visited the Alhambra

14 Arribas Palau, "El viaje del embajador marroquí," "Un embajador marroquí," "El embajador marroquí Muhammad b. Utman," "El paso de un embajador marroquí por tierras de Murcia," "Datos relativos a la actuación," and "La estancia en España de Muhammad Ibn Utman."

15 Arribas Palau, "Dos condenados a muerte indultados."

16 Rodríguez Casado, "Apuntes para una biografía."

17 Paradela Alonso, El otro laberinto, 88, and "El Madrid de los embajadores musulmanes."

18 Paradela Alonso, El otro laberinto, 77-78, 88, and "El Madrid de los embajadores." 
in Granada and monuments in Toledo. He had to withdraw from a visit to the great mosque of Córdoba because such a large crowd had come to see him, but a nighttime tour by candlelight was specially arranged..$^{19}$

Ibn Utman, like his predecessors, interjected condemnations of the Christians, saying, "May God destroy them!" and "May God cleanse the land of them!". He demonized friars in particular: "May God eliminate them and cleanse the land of them!". ${ }^{20} \mathrm{He}$ engaged in dialectic with some of the priests that he met. ${ }^{21}$

But at the same time he appreciated many modern features of the Iberian Peninsula: he praised the local agriculture, highway system, efficient administration, and the scientific knowledge and experiments that were shown him in Madrid and Cádiz. Throughout his travels he visited factories, among them those of silk and gunpowder in Murcia, of tobacco in Seville, and the mint in the same city, and he considered Madrid a fine urban space. ${ }^{22}$

Again like earlier envoys from Morocco, Ibn Utman tried to recover Arabic books from the library at El Escorial and to free Muslim captives. On seeing the library he reported: "In a great cabinet, perfectly kept and very clean, they have placed books of the Muslims - may God have mercy on them! - that have fallen into the hands of the infidels.... There are one thousand eight hundred volumes." He examined a few of the Arabic manuscripts and seems to have requested some of them; though he received several as gifts, those did not come from El Escorial but from some other collection. ${ }^{23}$ As we saw, he was able to free and return to Morocco over one hundred captive Muslims. ${ }^{24}$ Ibn Utman died in Morocco in 1799 during an epidemic of plague.

\subsubsection{An Unacknowledged Ambassador, Muhammad Al-Dalimi of Morocco (1792)}

On 31 May 1792 a French polacre, the Marie Thérèse, reached Cádiz from Mogador bearing Muhammad al-Dalimi, his secretary and interpreter Pedro Umbert, and twelve more members of his retinue. Al-Dalimi came to Spain

\footnotetext{
19 Paradela Alonso, El otro laberinto, 83, 88, and "El Madrid."

20 In the mosque of Córdoba he lamented all the chapels that the Christians had built inside it: Paradela Alonso, El otro laberinto, 81, 9o, and "El Madrid." Boudchar, "España vista por un embajador marroquí."

21 Paradela Alonso, El otro laberinto, 81-84, 88, and "El Madrid."

22 His remarks on the mint in Seville may have influenced the sultan's decision to have Moroccan coins struck there: Elamri, The Elixir, 23; Tazi, "Cádiz en el viaje de Muhammad Ibn Utman"; Paradela Alonso, El otro laberinto, 9o, 98-99; Boudchar, "España vista por un embajador."

23 Paradela Alonso, El otro laberinto, 69-70.

24 Paradela Alonso, El otro laberinto, 62.
} 
as ambassador from Muley Hisam, one of the pretenders to the throne of Morocco then held by al-Yazid. His destination was Madrid, but the local health authorities held the group in quarantine for fifteen days. The city governor, Joaquín Fonsdeviela, following instructions from the Secretariat of State, informed the Moroccans that the Spanish monarchy had a policy of strict neutrality in the struggle that set Sultan Muley al-Yazid against the three brothers who vied for his throne: Muley Hisam, Muley Muslama, and Muley Sliman. As a result no envoy from any of the four rival siblings or "princes" could be received or recognized. ${ }^{25}$ Therefore Al-Dalimi had no status as an ambassador; though he was well treated and allowed to disembark and stay in Cádiz as a private citizen, he was warned that he would not be allowed to travel to Madrid.

Muley Sliman, who finally captured the throne, was angry; knowing the Spanish policy of neutrality he had refrained from sending his own envoy to Spain, and assumed that al-Dalimi had been received there with ambassadorial rank. While al-Dalimi behaved correctly, the members of his entourage did not: Spanish authorities accused them of "spending wastefully" and acting with impertinence. To limit the cost of their stay - which included the days in quarantine - they were assigned a daily sum of fourteen pesos fuertes in addition to their housing, a male servant, and the care of the ambassador's two horses. Al-Dalimi himself merited a supply of wine and a balcony from which to view the bullfight. Two Spanish interpreters, José de la Cruz and Gabriel Gavaró, assisted the delegation.

It appears that al-Dalimi's chief mission was to obtain economic support for Muley Hisam, one of the pretenders to the throne. But it is possible that he had really been sent by Hisam's brother Muley Abd al-Salam, who wished to persuade a reputable doctor from Cádiz to travel to Morocco to treat him for cataracts. The envoy was also charged with making several purchases.

In the end the governor of Cádiz chartered a French brigantine of one hundred twenty tons, Le Réflexif under Captain Mathieu La Fevure, for the delegation's return journey, and the ship sailed for Mogador on 30 July. The cost was one thousand pesos for the round trip, one hundred against possible damages, and forty reales as a supplement. Al-Dalimi (who had visited other European countries and spoke some Spanish) received a gift valued at 9,155 reales and nine maravedís, as well as provisions for twenty days. The total cost to

25 The brothers began to contend for the throne after Muley al-Yazid's death in February 1792. Muley Hisam was proclaimed ruler in Marrakesh, Safi, and Mogador, Muley Muslama in Tangier and its hinterland, and Muley Sliman in Fez and Meknes: Arribas Palau, "Embajadas marroquíes a España" and "Nuevos datos sobre la embajada de Muhammad al-Dalimi." 
the treasury of al-Dalimi's stay in Spain came to 56,663 reales and seventeen maravedís. ${ }^{26}$

\subsubsection{The Ottoman Ambassador Vasif Effendi (Madrid, 1787-1788)}

In July 1787 the court at Istanbul sent Ahmet Vasif Effendi as ambassador to Spain, and he arrived in Barcelona in August. His mission was to secure peaceful relations between the two empires, promote economic ties, and probably also to relieve the pressure that Spain was exerting on the Ottomans to further its friendly connections with the Maghrebi regencies. We have the report or Sefâretnâme that the ambassador was required to submit on his return: it was supposed to describe the host country with special attention to its political administration, military strength, and economic activity in agriculture, industry, and commerce. These reports were taken into account when, in the early nineteenth century, the Ottoman Empire undertook modernizing reforms or tanzimat. ${ }^{27}$

Vasif reached Barcelona at the head of a suite of forty-five persons. ${ }^{28}$ Since he was a diplomat accredited to important foreign missions and an official historian, the tone he used in informing his government is rather surprising. His text could not have proved very useful, because he presented his mission as a series of disputes with Spanish authorities and bureaucrats; ${ }^{29}$ but in his own opinion, naturally enough, the result was a triumph for himself and therefore for the person of the caliph.

Vasif's report was intended for the caliph, the grand vizier, and other imperial authorities, but his mission does not seem to have achieved much to

26 Arribas Palau, "Nuevos datos sobre la embajada" and Una embajada marroquí.

27 I have relied on Meynard's French translation, "Ambassade de l'historien Vaçif Efendi," and the partial Spanish version by Onalp, "La crónica de Ahmet Vasif Effendi." They differ particularly in that the second moderates Vasif Effendi's tone, making Meynard's more reliable. I have also consulted Jurado Aceituno, "A propósito de Vâsif Effendi”; Paradela Alonso, El otro laberinto, 100-o3; Conrotte, España y los países, 89-91; and Matar, "Spain Through Arab Eyes."

28 He arrived on 25 July in the French corvette Elisabeth under Captain Gaspar Fardeloux, after a twenty-five-day journey from Istanbul: I M HB, Fs, Serie v, fols. 74-78, dated 28 July, 1 August, and 15 August 1787. A broadsheet published in Valencia the same year described him as "tall and stout, with olive skin and a heavy beard; affable, and about forty-five years of age." It listed the political and diplomatic posts he had held in his country. His delegation included a secretary, two dragomans, and a treasurer, the rest being servants: Burguete, Relación Nueva.

29 According to Meynard he produced "a simple report written in haste, in that tone of disdainful superiority that the Ottomans affected in their relations with Europe": "Ambassade," 505. 
boast about. Hispano-Ottoman relations were cemented more effectively by the presence in Spanish ports of Greek ships flying the caliph's flag that came loaded with wheat from the Black Sea and the Greek islands. ${ }^{30}$ Further, when Vasif Effendi reached Barcelona the Spanish monarchy had already signed peace treaties with the regencies of Tripoli (1784) and Algiers (1786). In Vasif's account it was the Spanish king who enunciated the chief purpose of his mission: to obtain full protection for the subjects of both empires during their travels for business or other matters. ${ }^{31}$

Vasif therefore stressed the difficulties he met during his mission. He was probably aware of its slight importance, which corresponded to the Spanish embassy to the Ottoman court in 1784 that had been scarcely more than a courtesy visit. ${ }^{32}$ The only modest success he could present to his superiors was his belief that Spaniards would have to accept Ottoman supremacy, however symbolically. He had described the caliph to Charles III as "the noblest king on earth: the illustrious, elevated, powerful, generous Emperor, my benefactor and master His Highness Sultan Abdul-Hamid-Khan," while referring to his Spanish counterpart as "the noble and distinguished king of Spain" - who, moreover, was an old man whose trembling hand could not hold the ambassador's letter of credentials, with "a nervous tremor that the letter's solemnity increased even more." ${ }^{33}$

Vasif's report, as we have observed, devolved into a tale of the conflicts or incidents he suffered from the Spanish authorities and, in his own opinion, emerged from in triumph for himself and the Ottoman cause. On two occasions he threatened to return home without having completed his mission. On his arrival in Barcelona he was informed that, after news of plague in several Levantine and Maghrebi ports, the nation's Supreme Board of Health had ordered a quarantine in the lazzaretto of Mahón for all ships proceeding from those cities. ${ }^{34}$ The ambassador was carrying a letter from Spain's Minister Plenipotentiary in Istanbul that exempted him from the quarantine or at least allowed him to serve it in Barcelona, but the minister was not entitled to make

$30 \quad$ Martín Corrales, "Capitaines et navires gréco-ottomanes" and "Greek-Ottoman Captains."

31 The king supposedly told him, "I hope that from now on the subjects and negotiators of our respective States will enjoy complete security": Meynard, "Ambassade," 513-14.

32 González Castrillo, El viaje de Gabriel Aristizábal.

33 He also thought that Count Floridablanca, the Secretary of State or Prime Minister, loved flattery and was "much inclined to adulation": Meynard, "Ambassade," 513, 516.

34 For sanitary measures taken in the port of Barcelona throughout the eighteenth century, and during the arrival of this ambassador in particular, see Martín Corrales, Comercio de Cataluña, 152-53. 
that decision..$^{35}$ After a lengthy argument Vasif told the local board of health that if he could not serve the quarantine in Barcelona "I have decided to return home after destroying the gifts I was bringing." ${ }^{36}$ Faced with this attitude the board of health, after receiving royal authorization, ${ }^{37}$ allowed him to serve out the period in the Catalan capital. ${ }^{38}$

On a second occasion Vasif argued with the chancellor and the master of ceremonies ("an Armenian born in Jerusalem whose perversity is unmatched") over whether or not he should offer gifts to the most important figures at court, including the princes and the Prime Minister. At one point in the tense encounter he again threatened to leave the country: “'Well then,' I cried, 'please give the orders for my immediate departure!"’39

A simple reading of the ambassador's report makes clear that he exerted pressure; after describing the various incidents involved he pronounced himself satisfied for having prevailed. On his threat to depart if his retinue could not serve the quarantine in Barcelona, he declared that "this won over their resistance." He also boasted of his refusal to offer gifts to anyone except the Spanish monarch, while describing the ones that he did distribute to officials in Barcelona, Valencia, La Granja, Madrid, and Cartagena. ${ }^{40}$

35 Port authorities in Barcelona informed the city's board of health that they could not accept the petition of the "Ambassador of the Sublime Porte" to spend the quarantine in Barcelona, since he was required to proceed to Mahón: Josep Barberi y Vila to Junta de Sanidad, 26 July 1787: IM HB, FS, Serie I, leg. 18, fol. 109. They proposed that the envoy be addressed "in the most correct, decorous, and urbane terms, so that His Excellency may be persuaded to take this step for the strong reasons that are presented to him, rather than by force or violence."

36 Meynard, “Ambassade," 507.

37 Count Floridablanca as Secretary of State and Pedro Rodríguez de Campomanes, an influential member of the government, were informed in good time of the ambassador's arrival, according to correspondence with the Capitán General of Catalonia: IMHB, FS, Serie VII, leg. 4, fols. 112-14, dated 3, 8, 14, and 18 August 1787. Also Serie VIII, leg. 1, fols. 283, 291-92, 25 July and 14 August 1787.

38 He was allowed to remain with only his ten most essential followers, while the rest left for Mahón to serve out the quarantine there. Orders were issued to provide him with every necessity (tents, pavilions, food, and refreshments) to maintain his dignity during the quarantine period: José Barberí y Vila to the board of helath (Junta de Sanidad del Ayuntamiento), 26 and 27 July 1787, IM HB, Fs, leg. 18, fols. 109, 111, 113; likewise fol. 112, Baron Linde to Junta de Sanidad, 27 July 1787. In his honor a commission, made up of important members of the city council and the Royal Magistrates' Court of Catalonia, agreed to reduce his quarantine by five days: José Barberí y Vila to Junta de Sanidad, 21 August 1787, fol. 129 .

39 Nonetheless he distributed gifts in Barcelona, Valencia, Madrid, and Cartagena: Meynard, "Ambassade," 515 .

40 Meynard, "Ambassade"; Burguete, Relación Nueva. 
Vasif presents other incidents as victories of his own or on behalf of his sovereign. After mounting a protest he managed to be classed as an ambassador extraordinary, rather than as the second-class one that he actually admitted to be, boasting of having persuaded the Spanish court that "personally I enjoyed a considerable rank at the Sublime Porte." He adds that European ambassadors at the court regarded him with envy. ${ }^{41} \mathrm{He}$ also balked at the Spanish protocol of waiting on the Secretary of State before meeting the king, and while he finally accepted, "it will be done incognito."42

Vasif expressed his anger on other occasions. In Valencia he presented the viceroy with a "richly adorned" purse and received two bottles of olive oil in exchange, causing him to describe Spaniards as sordid and stingy. He judged his lodgings at La Granja to be insufficient for his retinue. ${ }^{43} \mathrm{He}$ complained that his expenses in Spain were not fully reimbursed, noting that the Ottoman government financed the visits of Spanish ambassadors to Istanbul in full. ${ }^{44} \mathrm{He}$ founded all his complaints on the arrogance and ignorance of Spaniards, who were unaware of Ottoman diplomatic practices - the only ones that should be followed, in his opinion. ${ }^{45}$

Even Vasif admits that his comments are at odds with the signs of respect offered to him during his mission. The king granted him two audiences, and the Secretary of State met with him four times. The Captain General of Valencia invited him to supper after asking him to send over his own cooks.

The ambassador's report offers little information about the reality of Spain. It stresses the great excitement generated by his passage through different Spanish cities, an attempt to endow his mission with greater prestige. Of his thirty-two days in Barcelona he spent twenty-seven in quarantine in the lazzaretto, ${ }^{46}$ where he recalls the expectation that surrounded his presence there

41 He would not accept being treated "on a footing of equality with the envoys of other powers": Meynard, "Ambassade," 511, 514. In Barcelona and Valencia, "because he did not hold the rank of Ambassador, and was not a Pasha, he received no royal artillery salute or escort of guards flying the flag, and was given only the honors prescribed for a Lieutenant General, without any greater distinction": Bruguete, Relación Nueva.

42 Meynard, "Ambassade," 510.

43 On the character of Spaniards: "One may judge by this treatment alone the sordid and avaricious nature of Spaniards." On his lodging: "It could scarcely contain the members of the mission and the gifts": Meynard, "Ambassade," 509-10.

44 Meynard, "Ambassade," 510, 520.

45 "[T]he haughty character of the Spanish and their ignorance of the Imperial government's customs." Elsewhere in the report he refers to "the arrogant and presumptuous nature of Spaniards." He had explained to the Spanish master of ceremonies that European norms were invalid for the Ottoman caliph: Meynard, "Ambassade," 514-15. 
("the fence around it was weighed down by a crowd that greeted us from afar"), a curiosity that reached its height when the Ottomans moved into the city. So thick was the press that a fifteen-minute journey stretched to five hours: "Although the lazzaretto is no more than a quarter of an hour's walk from the town, it took us almost five hours to make the journey, so great was the crowd along our way." Something similar occurred in Valencia: "the crowd that blocked our passage as we made our way to our lodging was so thick that the soldiers could barely open a path for us through the people." The ambassador, to satisfy all their curiosity, "has eaten where everyone can see him, and has gone out several times in complete openness to view the shipyards, theaters, and other sights." ${ }^{\text {77 }}$ In La Granja likewise, "the crowd, drawn by curiosity, pressed with friendly astonishment along the path of the cortege." It grew as they grew closer to the king's quarters:

I cannot attempt to describe the gathering of people that this spectacle drew to our route. Five or six rows of spectators crowded onto the balconies, and I have been assured that windows were rented out at one hundred piastres. Carriages and coaches filled with the curious were stopped along the streets and made our passage slower and more difficult. ${ }^{48}$

In Madrid, interest centered on observing the ambassador at mealtimes. ${ }^{49} \mathrm{Va}-$ sif complained that the music played for him at noble houses in Madrid was "unbearable," though he seems to have enjoyed a fandango he heard in Barcelona. The musicians in his own train, however, pleased their audiences. In Barcelona he had "one of his musicians sing a good aria in Arabic, which he did, it being well received by all"; in Valencia he offered a concert of Turkish music with a band "composed of two flutes, a tambourine, a marine trumpet, and a violin; then a Turk sang some verses in Arabic." In Madrid "the musicians and singers who accompanied the mission had a great success." ${ }^{50}$

Vasif says little about the state of the Spanish administration, army, or economy, matters that would have been useful for his own country. His account of

Burguete, Relación Nueva; Meynard, "Ambassade," 508-o9.

48 "[J]e renonce à descrire le concours de peuple que ce spectacle avait réuni sur notre passage. Cinq ou six rangées de spectateurs se pressaient sur les balcons, et l'on m'a affirmé que des fenêtres avaient été louées cent piastres. Des voitures, des chariots encombrés de curieux stationnaient dans les rues, et rendaient notre marche plus lente et plus difficile." The king's children were also eager to see Vasif: Meynard, "Ambassade," 511-12, 514.

49 "An innumerable mob came to meet me, especially during meals; our customs seemed to surprise them very much": Meynard, “Ambassade," 511.

50 Burguete, Relación Nueva; Meynard, "Ambassade," 518. 
the military academy in Segovia is brief, though he does remark on its classrooms equipped with mathematical instruments, maps, charts, and other items. He notes that in the royal cloth factory in Segovia he saw splendid textiles, while the mint lay in ruins. He also comments favorably on what he saw of the transportation system. ${ }^{51}$

The ambassador makes an interesting assessment of commercial relations between Spain and North Africa; in spite of a few errors it is largely accurate, as well as proof of the pragmatism that reigned at the time in the country's contacts with Muslim countries. We quoted above his remark on Spain's need for imports of food from North Africa in exchange for gold and silver; that explained the monarch's respectful treatment of the sultan of Morocco, who sent precious metals obtained in that trade to be minted into coins in the Peninsula. ${ }^{52}$

Vasif shows little emotion concerning Spain's Muslim past, mentioning only that Segovia retained many traces of it. ${ }^{53}$ In a visit to El Escorial and its library of Islamic manuscripts, however, he displayed greater concern and regret:

When the Spaniards triumphed over the Arabs they gathered all the Islamic books and placed them in two rooms of this monastery. A fire consumed one of these collections, which numbered twelve thousand volumes. The remaining one includes about five thousand volumes and I was offered its printed catalogue. European works occupy the lower level, while the Muslim books are ranged on the upper one. Among them I saw, not without strong regret, several ancient copies of the Quran and a considerable number of works related to jurisprudence, theology, and traditions. ${ }^{54}$

Vasif's limitations as an ambassador and his effort to enhance his reputation with his superiors show most clearly in his opinions about the Spanish-Algerian

\footnotetext{
$51 \quad$ Meynard, "Ambassade," 517.

52 Paradela Alonso, El otro laberinto, 102-03; Meynard, "Ambassade," 512.

53 Meynard, "Ambassade," 517.

54 "Quand les Espagnols triompherent des Arabes, ils réunirent tous les livres musulmans et les placèrent dans deux salles de ce monastère. L'incendie dévora l'une de ces collections, qui renfermait douze mille volumes. Celle qui existe encore compte environ cinq mille volumes, dont le catalogue imprimé me fût offert. Les ouvrages européens occupent l'étage inférieur, et à l'étage superieur sont rangés les livres musulmans, parmi lesquels je vis, non sans de vifs regrets, plusieures copies anciennes du Coran, et un nombre considérable d'ouvrages relatifs à la jurisprudence, à la théologie et aux traditions": Meynard, "Ambassade," 518.
} 
peace treaty of 1786. He reported with disdain that while Spain had been generous to the Dey, supplying Algeria's arsenals with military equipment and ransoming twelve hundred Spanish captives at a thousand reales a head (even paying for those who had died during the negotiations), Algeria had given in exchange only three horses, two lions, and a few ostriches. The Dey, "to show his contempt even further," had handed the animals over to the Spanish consul in Algiers so that Spain would have to pay for their transport to the Peninsula. Vasif declares that Spain emerged more humiliated than any other Christian power: "One can judge by these examples with what humility [Spain] abases itself, more than all the other infidel governments, before the pious disdain of the Algerians." ${ }^{55}$ Obviously, this attitude did not leave much scope for the Spanish government to discuss with the Ottoman ambassador its relations with the Regency of Algiers. It is further proof that Vasif's embassy should be considered as almost a visit of courtesy without any concrete objective.

After an eight-month stay in Spain - we do not know what he did toward the end of that time - Vasif embarked in Cartagena on 1 April 1788 in the frigate Santa Rosa under Captain Federico Gravina, who conveyed him back to Istanbul. In May of that year Juan de Bouligny told Count Floridablanca that Vasif Effendi had been "very grateful and satisfied about the treatment and attention he received during the sea voyage," adding that "until now he has not ceased to praise the benignity, generosity, and magnificence of His Majesty and our Court in attentive and grateful terms, assuring me that Spain is a great power and an intimate friend of the Porte." ${ }^{56}$ As we already know, he changed his mind when he put pen to paper. We have a translated letter from the ambassador in which he acknowledges his good treatment by the captain of the Spanish frigate that took him to Constantinople and describes the Spanish court as "our friend":

Having been sent by order of the Sublime Porte as an ambassador to the West, by a similar order I now return. I have assured the court of this through the bearer of this [letter], the brigadier and commander in the service of the court of Spain who is our friend, named Don Felipe López Carrizosa. I cannot fail to say in his praise that we have been treated on all occasions with the greatest distinction; with unquestionable proofs they have always shown us much more than we could have expected; and we are most happy with the commander and his officers. And that he

55 Meynard, "Ambassade," 521-22.

56 Gravina, Descripción de Constantinopla, 36. 
may show our satisfaction on his return to Spain, we have given him this letter. $^{57}$

\subsection{Muslim Ambassadors Who Passed through Spain}

As we noted at the beginning of this chapter, there were other ambassadors who stopped over at Spanish ports during journeys to or from the courts to which their sovereigns had sent them. Most of our information concerns Moroccans, a testament to the good state of Spanish-Moroccan relations, but this group also includes Algerians, Tunisians, Tripolitans, and Ottomans. Further research will surely identify even more than those we discuss here. It is difficult to establish to what extent they were true ambassadors sent on particular missions, or simply persons who, with the pretext of a pilgrimage to Mecca, were bearing gifts for the caliph in Constantinople or on some similar journey.

Some of these men reached Madrid, where none of them was received officially although almost all sought to be. The objectives of their journeys were various European capitals, although some were bound for Istanbul and other points in the Islamic world. Most of them were conveyed free of charge to and from their destinations in Spanish warships, the rest traveling in private vessels that were also financed by the Royal Treasury. ${ }^{58}$

Paying the cost of transporting and maintaining ambassadors to a court was a common practice in Europe, North Africa, and the Ottoman Empire, and was often extended to diplomats who were merely in transit in ports of those countries. We wish to stress here that most of the envoys who stopped in Spanish ports took advantage of the ambiguities inherent in international diplomatic norms, the texts of the Treaties of Peace and Friendship, and local customs and usages to gain extra financial support for their missions. They would argue

57 "Haviendo sido embiado pr orden de la Sublime Puerta en calidad de embajador al Occidente por orden de la misma deviendo regresar, lo he verificado a esta corte con el portador de la presente que es el Brigadier y comandante a el servicio de la Corte de España nuestra Amiga, llamado dn. Felipe Lopez Carrizosa. No puedo dejar de decir en su elogio, sino que hemos sido tratados en todas ocasiones con las mayores distinciones, y con pruebas nada equivocas que nos han demostrado en todo tiempo mucho mas de lo que podíamos esperar; y estamos mui contentos del sr. Comandante y oficiales; y para que manifieste a su regreso a España nuestra satisfaccion le hemos dado la presente carta": letter conveyed by the Ottoman court to Spain's dragoman in Constantinople, dated 12 April 1788, AHN, Estado, leg. 4316.

$5^{8}$ I will not discuss here those who were transported by third parties, in warships or private vessels. 
openly, or at least suggest, that their governments did not provide them with sufficient funds, forcing them to rely on their private resources. They were able to exploit the concern of successive Spanish governments for obtaining favorable interlocutors in their relations with Morocco, and the same was true to a greater or lesser extent of ambassadors from other Muslim countries. These individuals, aware of their usefulness in defending Spain's interests in their respective homelands, did not hesitate to request generous grants and loans in exchange for future favors in their countries of origin. While some fulfilled their promises to further Spain's causes, others did nothing of the kind, and resented not having received the respect they thought was due to them.

\subsubsection{Moroccan Ambassadors in Search of Free Passage}

The largest contingent of ambassadors who stopped over in Spain were Moroccans sent on diplomatic missions by their sultan. This should not surprise in view of the conditions of navigation at the time and Spain's strategic location for Moroccan travelers in ships of their own country or others. ${ }^{59}$ The ruler usually asked Spain's consul general in his country to charter a ship to take an ambassador to his eventual destination. These orders, as translated by the consul's interpreters or those of the court, are couched in an imperative tone - sometimes treating the consul as a slave, sometimes as a friend - that never admits willingness on the sultan's part to assume the costs of the voyage. We should view this attitude by the ruler or his ministers and governors as reflecting the privileges and benefits that the Spanish enjoyed: exemption from, or reduction of, customs duties on the export of Moroccan products; commercial advantages such as the monopoly on exporting wheat from Dar al-Beida, etc. For the sultan (and for some Spanish authorities, as documents show) free voyages were a kind of payment for these concessions, the counter-gift that matched the original gift. ${ }^{60}$

The port city of Cádiz played an important role in these arrangements, since many of the persons we are about to describe passed through it on their outward or homeward journeys. ${ }^{61}$ The whole area of the Bay of Cádiz was

59 Among many possible examples is that of the Moroccan corsair frigate assigned to carry Ambassador Sid Mahamet Ben Abdeljadi to Malta in 1781. Tangier's governor asked the Spanish consul in his city to recommend the ambassador to authorities in Málaga in case the ship had to dock there: Juan Manuel González Salmón to Count Floridablanca, Tangier, 27 March 1781, AHN, Estado, leg. 4314.

6o Recall the reciprocity of gifts and counter-gifts between the sovereigns of Morocco and Spain mentioned in section 4 of Chapter 5:J.M. González Salmón to Count Floridablanca, 9 October 1789, AHN, Estado, leg. $43^{21 .}$

61 I will speak only of embassies that are formally documented, although we infer that many other cases could be cited. A large number of the sultan's many embassies were headed 
important to Hispano-Moroccan relations, especially in the realms of trade and diplomacy. ${ }^{62}$

\subsubsection{Sid Brahim al-Mansur (1774)}

We do not know if he is the same man who appeared in Cartagena in 1767 bearing the title of Admiral; only that in 1774 he was supposed to embark in Tetouan on a mission to the French court. From Tetouan he would proceed to Algeciras where he and his retinue would disembark and then travel to France by land, but we do not know if that journey was ever made. ${ }^{63}$

\subsubsection{Tahir Fannis $(1777-1778)$}

Tahir Fannis, or Sidi Tahir Ben Abdalhaqq Fannis, was an alcaide and also commander of the Moroccan artillery; he led several embassies to countries and capitals including London (1773), Paris (1777-1778), and Istanbul (1788). ${ }^{64} \mathrm{On}$ his mission to the French capital he passed through at least one Spanish port. Although the sources are not entirely reliable, everything indicates that the ship taking him to Marseille stopped in Barcelona in November 1777. The city's governor ordered port officials to provide "everything that the ambassador may need in the way of provisions," while taking the usual precautions as to health; the ship took on twelve casks of water and "twenty ordinary wooden planks." ${ }^{65}$

In August 1780 Fennis was sent to Cádiz, in an unknown rank or position; he arrived aboard the Moroccan frigate La Maymuna of fourteen guns under Captain Ali Sabuny. The statement by the Spanish authorities that "he comes with orders from his sovereign to carry out certain commissions given to him orally" is corroborated by a letter from the sultan: "the matters that he will convey in person to you from us, having to do with our commissions." He was

by a relatively small group of alcaides and captains, but I limit myself to those I can document.

62 Martín Corrales, "Le commerce de la bahie de Cadix," "El comercio de la bahía de Cádiz," and "El comercio de Cataluña con Marruecos."

63 Isidro Romero Berganza, Spain's vice consul in Salé, to Marquis of Grimaldi: Salé, 5 September 1774, AHN, Estado, leg. 4312.

64 His name is variously transliterated as Tahar Fennich, Tahar Fannis, Tahir Fannis, and other forms. See Arribas Palau, "Al Tahir Fannis en Cádiz”; Caillé, "Les naufragés de la Louise."

65 The port captain reported that the ship had arrived from Gibraltar in the afternoon of 5 November: "The ambassador of the Emperor of Morocco who arrived this afternoon, [with] the French captain Estevan Lambert in his brigantine coming from Gibraltar, requests the provisions described in the attached paper, which is what he needs for now": Onofre Segura to Marquis of Llió, 5 November 1777, Ім Hв, Fons de Sanitat, Serie X, legajo 8; Caillé, "Les naufragés de la Louise." 
accompanied by eleven family members, a gentleman friend, two secretaries, an interpreter, a chamberlain, two pages, a cook with his assistant, a drum major, and a doorman. The Bourbon treasury paid for the retinue's expenses and lodging during its stay in Cádiz. Antonio de Gálvez, the city treasurer, reported to its governor, Count O'Reilly, that the payments were necessary "since I know the character of that Moorish prince and his vassals, and how convenient it is in today's critical circumstances [the war between Spain and England] to keep them happy." ${ }^{\prime \prime 6}$

One of Fannis's commissions was to hear the petition of some Maltese who had been seized out of a Ragusan ship by a Moroccan frigate. He was also to acquire wheat, which was scarce in Morocco at the time. In Cádiz he was allowed three hundred fanegas of three different grades of wheat, which were shipped in the frigate to Salé the following month. On 1 October Gálvez informed O'Reilly that "I have not received an order to collect payment for the three hundred fanegas of wheat that I sent to the emperor as samples following the instructions in your letter, for which he was so grateful, doubtless because he took them for a gift." ${ }^{\prime 7}$ The governor wrote in turn to the Secretary of State, explaining that such situations were frequent: "as it often happens that Moors sent by His Moroccan Majesty arrive at this port, I cannot help reminding Your Excellency that you should inform me of what is best to be done." 68

Fannis returned to Tangier on 7 November in a brigantine that bore a gift for the sultan of Morocco. He left behind his secretary and four other Moroccans in the house assigned to them, thus incurring more expenses for the Spaniards. The governor explained to the Secretary of State why it was best to pay them:

I am always concerned that the Moor Taher-Fenix or another chosen by the king for his commissions will return to this port, and Your Excellency will decide if in this case a daily sum should be provided to support him decently or if he must support himself; and I must tell Your Excellency that when Taher Fenix came he told Lieutenant-Colonel Don Antonio de Gálvez that he had brought no money of his own. We expect that any

66 My fundamental source is Arribas Palau, "Al Tahir Fannis en Cádiz": he consulted the documents on the case found in legajos 4315 and 5806 of the Estado section of AHN. The quotation from the letter from Antonio de Gálvez to Count O'Reilly, 16 September 178o, is in AHN, Estado, leg. 4315.

67 Antonio de Gálvez to Count O’Reilly, Cádiz, 16 September 1780, AHN, Estado, leg. 4315.

68 Count O'Reilly to Count Floridablanca, 17 October 1780, AHN, Estado, leg. 4315. 
other who comes on the king's behalf will say the same and assume that his expenses will be paid. ${ }^{69}$

The king ordered payment of the expenses Fannis had incurred. Meanwhile, Gálvez reported that he had arranged for the remaining members of Fannis's retinue to leave the city:

I have their agreement to carry it out [the return to Tangier] at the earliest sign of good weather, for which I have ready a felucca among those that I charter. And I will ensure that in the future there will be no more costs than those necessary ones Your Excellency commands. ${ }^{70}$

The Secretary of State approved the plan, notifying the governor of Cádiz that he should end "the habit that [Moroccans] may be acquiring" of arriving in a Spanish port and staying there without any motive except to enjoy "the comforts and support" they received from the public treasury. He added that "it is not the same to spend on a prince's ambassador as on a private citizen who comes to discharge a few errands of a purely commercial nature." He instructed the governor to "see how you may rid yourself politely" of the Moroccans who had stayed behind in Cádiz, suggesting to them that, "since they had received all the attention they could expect from the government in facilities for their business, they should take care of their own maintenance." Still, Floridablanca thought it better "to assign each of them a reasonable daily amount than to let them spend freely according to their whims."71

Governor O'Reilly "insinuated" to the Moroccans still in Cádiz "that they should seize such a good occasion to see their sovereign, who would disapprove of their remaining here without any pressing reason." He agreed with the

69 "[S]iempre recelo que se restituirá a esta plaza el moro Taher-Fenix u otro que elixa el Rey para sus encargos y V.E. resolverá si, en este caso, se le ha de señalar algún diario para su decente manutención o si se dexará que lo costee por si; debiendo yo decir a V.E. que, quando vino Taher Fenix, manifestó al teniente coronel don Antonio de Galvez no haver traido dinero suio, es de recelar que qualquiera otro que venga por comisión del Rey dirá lo mismo, esperando que se le hará el gasto": Count O'Reilly to Count Floridablanca, 14 November 1780, AHN, Estado, leg. 4315.

70 "[T]engo consentidos en que la efectúen al primer buen tiempo que se presente, para lo que les tengo prevenido un falucho de los de rentas de mi mando, y procuraré con buen modo el que en lo subsesivo no se hagan mas gastos que los que V.E. mande y sean precisos": Gálvez to Count Floridablanca, 5 December 1780, AHN, Estado, leg. 4315, caja 1.

71 Floridablanca to Count O'Reilly, San Lorenzo [El Escorial], 28 November 1780, AHN, Estado, leg. 4315, caja 1. 
Secretary of State "that it would be easiest to follow the rule of treating them with welcome and favor in their business, while allowing them to pay their own way"; otherwise the visitors would abuse their privilege "and then feel more entitled to the custom and be more offended when it was taken away."72

Faced with this situation, Fannis told the governor of Cádiz in November that the Emperor had ordered the departure of the Moroccans who had no more reason to remain in the city:

There are many Muslims in Cádiz who have no merchandise, because the former governor here, Wald Ballah, would authorize anyone who wished to travel to Christian lands to do so, and in this he was not right. And today our lord has ordered the Muslims who are living among you to return, and has commanded al-Prubi and the governor here not to authorize travel to Christian lands except to those who own property and are of good reputation, and who will bear letters from them to you so that no error is committed. For my lord does not wish anyone to deceive such as to cause losses to a Spaniard by a Muslim or to a Muslim by a Spaniard, so that their mutual relations can remain correct.

Specifically, Fannis stated that Moroccans traveling to Cádiz would have to show a permit from the governor of Tangier or from Muhammad al-Prubi, who oversaw the Moroccan customs posts of Tetouan and Tangier. ${ }^{73}$

Fannis described accurately what had happened with various ambassadors, envoys, and emissaries: on arrival they would declare that the sultan had given them no funds to purchase the goods he had sent them to Cádiz to obtain. No doubt this was true, but it forced the Spanish authorities to provide the goods for free, as gifts, while at the same time paying for the expenses of the envoys' stays in Spain. The Spanish preferred to "keep the Moroccans happy," but these

72 O'Reilly to Count Floridablanca, Cádiz, 5 December 1780, AHN, Estado, leg. 4315, caja 1.

73 "[E]n Cádiz hay numerosos musulmanes que no tienen mercancías, porque el governador que había aquí, que era Wald Ballah, a todo el que deseaba pasar a tierra de cristianos, se lo autorizaba, y en esto no era justo. Y nuestro señor ha ordenado hoy que los musulmanes que hay junto a vosotros regresen; $y$ ha ordenado a al-Prubi y al governador que hay aquí que no autorice el paso a tierra de cristianos sino a quien posea bienes y tenga buena reputación, el cual llevará cartas para ti de ellos para que no ocurra ninguna falta, porque mi señor no quiere que nadie engañe causando pérdidas a un español junto a un musulmán ni a un musulmán junto al español a fin de que el trato entre ellos se mantenga correcto": Arribas Palau, "Al Tahir Fannis." Tahir Fennis wrote in Arabic to Governor O’Reilly of Cádiz on 25 November 1780: translation in AHN, Estado, leg. 4315, caja 1. 
repeated and costly abuses explain why by 1780 they had decided to set some limits.

Fannis may have been one of two Moroccan ambassadors who were returning from a mission to Istanbul in October 1783. Sidi Abd Ali and Abd-Ardé Ferric arrived in Cartagena on 22 October aboard a polacre from Ragusa, proceeding from Istanbul with stops in Chios and Tunis. Their retinue consisted of twelve persons. After taking on water and wood they sailed for Tangier the next day. ${ }^{74}$

Fannis reappears in Spanish sources when a new mission took him to Istanbul in 1788. This time he traveled in the Spanish frigate Santa Cecilia under Captain Felipe López Carrizosa. José Moreno, who in 1790 published an account of an earlier voyage to the Ottoman capital in 1784 , added an appendix about that of 1788 :

The steady friendship of our late king [Charles III] with King Mohamet Ben-Abdalla of Morocco and Fez was displayed with notable actions. One of them, not the last, was when the Moorish sovereign in late 1787 requested two warships from Spain to return to Constantinople a Turkish ambassador and a minister who were then in his domains, and also to convey another ambassador from His Moroccan Majesty with his gifts for the Great Lord.

In February of that year the Spanish frigate embarked Fannis in Tangier together with an Ottoman ambassador and minister about whom I will speak later; the retinue numbered seventy-four persons in all. They sailed to Cartagena where they were joined by the brigantine Ardilla, and in April both warships departed for Istanbul. Both ambassadors left written thanks for the good treatment they received from both ships' captains. The expedition tried to fulfill another desire of the sultan's: to stop in Alexandria to pick up his son, Prince Muley Abdelmelek, who would be on his way home to Morocco after making the pilgrimage to Mecca. It did not succeed because the prince did not appear, but the sovereign appreciated the gesture. ${ }^{75}$

74 The polacre was the Virgen de Gracia under Captain Nicolas Papi: Martínez Rizo, Fechasy fechos, 2:205.

75 "La constante amistad del Rey Padre con Mohamet Ben-Abdallá, Rey de Marruecos y de Fez, se mostró con obras señaladas. Una, no la última, fue quando el Soberano Moro, á fines de 1787, pidió á la España dos buques de guerra para volver a Constantinopla un Embaxador y un Ministro Turcos, que se hallaban en sus dominios; y llevar también otro Embaxador de S.M. Marroquí con sus regalos al Gran Señor": Moreno, Viage á Constantinopla, Appendix xxv-xxvi; González Castrillo, El viaje de Gabriel Aristizábal, 81. 


\subsubsection{Muhammad b. Abd al-Malik (1782-1783)}

The governor of Tangier, Muhammad b. Abd al-Malik, presents another good example of how Moroccan ambassadors took advantage of Spanish help in their missions to other countries. In 1782 the Moroccan emperor named him ambassador to Naples, Tuscany, and Vienna. Abd al-Malik then asked his friend Juan Manuel González Salmón to charter two ships on his behalf: both were from neutral countries, Venice and Sweden respectively, and had arrived in Tangier in June. On receiving the contracts the ambassador argued that he could not be expected to pay them in the light of services he had rendered to Spain (which was true), and because the sultan had not provided him with funds. González Salmón replied that his embassy did not concern Spain at all, and that he should not have waited until the last minute to make his demands. The sum of the two charters for a four-month period came to 5,691 pesos fuertes, and the governor claimed he would have to sell his jewelry to pay that amount. González Salmón wrote to Count Floridablanca as Secretary of State suggesting that the ambassador be granted three thousand pesos fuertes, half in advance and half at the end of the mission. ${ }^{76}$ The ports of Málaga, Cartagena, Alicante, and Barcelona were alerted that the embassy might stop there, to avoid inconveniences to the ship and its passengers even though they might have to serve a quarantine. The Spanish ambassador to Tuscany was ordered to welcome the Moroccan ambassador and give him introductions. Abd el-Malik left Tangier on 18 September 1782 accompanied by twenty-seven Moroccan Muslims and two Jews; they paused in Almería (23 September) and Alicante (3 to 7 October), where they were properly housed. The ambassador gave the governor of Alicante a note expressing his satisfaction, stating:

I certify that on my arrival in this harbor I have been complimented, greeted, received, and attended with all decency, promptness, and abundance of what has been offered for my lodging and maintenance and that of all my retinue, without reserve or stint, in rooms, waiting at table, beds, and all else touching on what is proper to my station, as well as in the prompt supplying of requests for provisions for continuing our voyage, in what concerns meats, fowl, bread, greens, fruit, and other foods; also

76 The incident is abundantly documented. J.M. González Salmón, the Spanish consul with whom Abd el-Malik discussed his finances, wrote that "it is no fault of ours that the king his master is stingy even with his own vassals": Tangier, $16 \mathrm{July}$ 1782. Abd al-Malik wrote to Count Floridablanca from Tuscany that he had received the sum agreed upon, "a kind act for which God will reward you”: Abd al-Malik to Count Floridablanca, 17 September 1782, AHN, Estado, leg. 4314. 
what concerns barley, straw, wood, and other utensils and necessities for the care and maintenance of twenty horses and the building of their stalls - all without having spent from my treasury any amount in payment of the above and all else that has been provided.

The governor of Alicante added that the ambassador had also been given sugar, spices, chocolate, gunpowder, and other items. After completing their mission the ambassador and his suite returned to Alicante on 9 August 1783, aboard the Ragusan polacre La Felicidad under Captain Miguel Lupi. Again they spent several days ashore, lodged and welcomed as before, and did not sail until 12 August. The ambassador's first stay in Alicante cost 1,241 libras, seventeen sueldos, and nine dineros in local currency; the second, 446 libras, five sueldos, and eight dineros. Together they came to almost thirty thousand reales de vellón, which were reimbursed to the city by the Royal Treasury. On 20 August the embassy docked at Tangier, and once Abd el-Malik had regained his post as governor he made several demands on the Spanish consul, who told the Secretary of State that it was best to satisfy him and keep him "entirely devoted to us."77 Finally, in May 1784 the governor was informed that Spain would grant him another forty thousand reales, for which he gave thanks. ${ }^{78}$ Meanwhile Abd elMalik tried unsuccessfully to be reimbursed by his own sovereign, but returned from an audience at court unhappy:

He did not come back very satisfied, for it seems [the sultan] does not want to repay him for any of the costs of his embassy to Vienna; this has made him angry and eager to find some money. ${ }^{79}$

77 J.M. González Salmón to Count Floridablanca, Tangier, 5 September 1783, AHN, Estado, leg. 4317 .

78 "Certifico que a mi arribo a esta bahía he sido cumplimentado, saludado, recibido y agasajado con toda decencia, prontitud y abundancia de quanto se ha ofrecido para mi alojamiento y manutención y de toda mi comitiva, sin reserva alguna, ni escasés, así en la habitazion como en la asistencia de la mesa, camas y demas respectivo al decoro de mi carácter, como en el apronto y servicio de quanto se ha pedido de prevenciones para la continuacion de mi viaje, tanto por lo tocante a carnes, aves, pan, verduras, frutas y otros viveres, quanto por lo perteneciente a sevada, paja, leña y otros utensilios y menesteres para el conreo y conservación de veinte caballos y composición de sus estancias, sin haber librado de mi Thesorería cantidad alguna para el pago de lo referido y demas que se ha suministrado": Arribas Palau, "Un embajador marroquí en Alicante."

79 "No viene mui satisfecho, porque parece no le ha querido pasar ningún gasto de los ocasiones en su Embaxada a Viena y esto lo trahe digustado y con muchas ganas de recoger dinero": J.M. González Salmón to Count Floridablanca, 27 March 1784, AHN, Estado, leg. 4317 . 
Clearly, Spain assumed significant costs for an embassy unrelated to its own affairs, in order to remain in the good graces of the governor of Tangier. The governor, in turn, did not hesitate to trade the favors he had offered for free charters and soujourns in Spanish ports.

\subsubsection{Hach Ben Mohamet (1782-1783)}

In 1782 Hach Ben Mohamet embarked in the English frigate La Colom (so called in the Spanish source: The Dove?) on an embassy to the court in London from the Moroccan sultan, but his vessel was seized by Spanish ships of the line and taken into Cádiz. The Moroccan was detained (though "treated decently"), accused of being a spy and of serving as an expert on English ships when they were being pursued along the southern coast of Portugal by the English. The Secretary of State sent an order to the Spanish consul in Tangier and Father José Boltas:

Both of you must complain to His Moroccan Majesty that this man has come as a spy and ally of the English, and make him understand that the man should be punished as he deserves. ${ }^{80}$

By January 1783 the Secretariat of State had taken a fresh interest in his situation. ${ }^{81}$ An undated, unsigned memo noted that the ambassador "at this time is at the home of the acting commander of La Carraca, where he is treated with deference until it is decided what to do with him." In April of that year the governor of Cádiz wrote to Count Floridablanca that because "the Moor Haggi Ben Hamet has frequent bouts of madness, or pretends to," he had been confined incommunicado in the castle of Santa Catalina. ${ }^{82}$ In June 1783 Count Floridablanca wrote to the governor of Tangier that

$80 \quad$ "...se quexen ambos a S. M. M. de que este hombre viniese por espia y practico de los Yngleses y hagan entender a S. M. M. que el Rey espera lo haga castigar como merece." Ben Mohamet had touched at Cádiz in December 1781 on a journey to Marseille "for private business." The Spanish doubted in principle that the Moroccan sultan had really sent him to England, but two of his letters that came to light proved that his trip to the British Isles was an official one: Count Floridablanca to J.M. González Salmón, San Ildefonso, 18 October and 1 November 1782, AHN, Estado, leg. 4316.

81 He also appears as Haggi Ben Jamet and Ben Hamet. Draft of a letter from El Pardo to Juan Manuel González Salmón, Spain's consul general in Morocco, 21 January 1783; shortly afterward the consul referred to him in a letter to Count Floridablanca. Both documents are in AHN, Estado, leg. 4317.

82 Count O'Reilly, governor of Cádiz, to Count Floridablanca, Cádiz, 29 April 1793. AHN, Estado, 5809-5810, Exp. 19. 
the king, who so values the friendship and person of His Moroccan Majesty, has graciously ordered that the Moor Haggi Ben Jamet be placed at liberty or sent to Tangier at your disposal. He was imprisoned in Cádiz because his statements and papers confirmed our information that he was a very suspicious figure for us, having come from London during the war with important messages for the British Cabinet.

That same month he was turned over to the governor of Tangier, though Spain asked that he be spared the death penalty. ${ }^{83}$ But Ben Mohamet met a tragic end. Perhaps because of the madness that was detected in Cádiz, he proclaimed in public that Mohammed was not the true Prophet, on which the sultan of Morocco ordered

that while he was alive his tongue, feet, and hands be cut off, and then four explosives be placed on his head and chest, a sentence that was carried out at once. ... He was given this death for having spoken too freely to the king, and after His Majesty had told him to declare publicly that Mohammed was the true Prophet and the messenger of God, he refused to do so; because of which the sovereign resolved to take his life in the manner described. He then commanded eight Jews to bury the body in the cemetery of the Hebrews, saying that he was like one of them and not a Mohammedan. And though it was claimed that he was entirely mad, that did not allow the unhappy man to avoid suffering an unfortunate death, nor did he have to give the slightest information about his mission, false or true, to London, for he was not questioned about that point.

The Spanish authorities never learned the reason for Ben Mohamet's embassy to London. ${ }^{84}$

83 "[E] el Rey que tanto aprecia la amistad, y persona de S. M. M. ha condescendido en que se ponga libertad u se pase a Tanger a la disposición de V.S. al Moro Haggi Ben Jamet, que estaba detenido en Cadiz, de resultas de haberse confirmado con sus declaraciones, y papeles las noticias de que se tenían de ser hombre muy sospechoso para nosotros habiendo venido de Londres durante la guerra con comisiones importantes al Gabinete Britanico": Count Floridablanca to J.M. González Salmón, Aranjuez, 6 June 1783, AHN, Estado, leg. 4316. González Salmón had earlier reported that he had ordered the Moroccan embarked on the xebec San Lino, "which will surrender him as I am assured he will be received": letter to Count Floridablanca, Tangier, 4 April 1783, AHN, Estado, leg. 4317.

84 “...[Q]ue le cortasen vivo la Lengua, pies y manos, y después le echasen a mano quatro Bombas sobre la Caveza y el Pecho, cuia sentencia se executó inmediatamente...Se le ha dado dicha muerte por haber hablado al Rey con demasiada libertad, y haviendole dicho S.M. declarase en publico como Mahoma era verdadero Profeta y enviado por Dios, no 


\subsubsection{Sid Amar Ben Ayà (1783)}

In June 1783 the sultan of Morocco named Sid Amar Ben Ayà his ambassador to the States General of Holland, ordering him "to embark for Cádiz, where the consul of Holland resides." There he "swiftly" found a ship to carry him to his destination. Ben Ayà took ship in Tangier on a Spanish felucca bound for Cádiz, with a suite of sixteen persons and their belongings. ${ }^{85}$

\subsubsection{Muhammad b. al-Hadi al-Hafi (1784-1789)}

The envoy known as Sidi Abdelladi, Hadj Abdelladi, or Abdeladi Selaoui was dispatched to Malta on several occasions (1769, 1781, 1784, and 1789), charged with helping Muslim slaves there and ransoming as many as possible. On his first two missions he must have touched at Spanish ports, though I have not yet found the documentation. ${ }^{86}$ In 1784 he asked the Spanish consul in Tangier, González Salmón, to alert Spanish ports in case his Moroccan frigate should stop over in any of them. He embarked for Barcelona with five companions in May 1784 in a Ragusan ship. Off Cape Licata in Sicily they crossed with the Spanish warship El Triunfante commanded by Gabriel de Aristizábal, which was carrying two envoys of the Moroccan sultan, Allal al-Awdi and Qaddur

lo quiso hacer; en vista de lo qual resolvió el Soberano se le quitase la vida en los términos expresados, y después mandó llamar á ocho judíos, para que se le diese sepultura al Cadaver en el Simenterio de dichos Ebreos diciendo S.M. que era como uno de ellos, y no Mahometano; y aun que se asegura que se hallaba enteramente demente, no le valió al infeliz para que dexase de sufrir una desastrada muerte, ni tubo que dar el menor descargo en punto á la comisión que llevó fingida, o verdadera, á la Corte de Londres, pues no se le tocó sobre este punto." On the letter's cover is written: "Cruel death that His Moroccan Majesty has decreed for the Moor Haggi Ben Jamet, who was captured by our men in the English frigate El Colón, and was detained in Cádiz (as a result of having traveled to London with a commission from the King of Morocco during the war)": J.M. González Salmón to Count Floridablanca, 27 March 1784, AHN, Estado, leg. 4317. There are references to someone whom the sources call "the Moor Haggi Ben Jmet, who is detained in Cádiz," who had a commission and passed through Sanlúcar de Barrameda, but he does not appear to be the same man, since the dates fall after Ben Mohamet's execution: J.M. González Salmón to Count Floridablanca, 27 June 1783, AHN, Estado, leg. 4317.

85 J.M. González Salmón to Count Floridablanca, Tangier, 4 June and 14 July 1783, AHN, Estado, leg. 4317. Some of his baggage had to be conveyed in a different ship that was chartered for eighty duros: J.M. González Salmón to Count Floridablanca, Tangier, 24 July 1783, AHN, Estado, leg. 4317 .

86 In March 1783 he asked the Spanish consul in Tangier to recommend him in case he stopped in Málaga on his way to Malta: "The ambassador himself and the Commander of Artillery of this port have asked me for a recommendation in case there is a stopover in Málaga." The consul wrote to the Count of Xerena asking him to attend, "preferably, others of his nation”: J.M. González Salmón to Count Floridablanca, Tangier, 27 March 1781, AHN, Estado, leg. 4314 . 
al-Awdi, to Istanbul; al-Hafi transferred to that ship to travel with them to the Ottoman capital. ${ }^{87}$ On his return in late 1786 he landed in Barcelona and went on to Madrid:

During his stay in Barcelona he has shown very polite and flattering behavior and the same has occurred here. Therefore, since he hinted that he was short of money and asked for the loan of a sum to be repaid on his return to Rabat, on order of His Majesty he has been given twelve thousand reales de vellón. He has left a receipt for it, which I send to you to have in your keeping.

The receipt stated in Arabic:

In acknowledgment of the debt of him who writes it, Muhammad b. 'Abd al-Hadi al-Hafi, six hundred Spanish pesos fuertes to the Count of Floridablanca, which he shall pay to the Spanish consul in Tangier.

Al-Hadi, worried that rumors might circulate about his doings on Malta, asked protection from the king of Spain; that ruler wrote to the sultan praising the Moroccan's dealings on the island and assuring him that his delay in Spain had been caused by illness. 88

He reached Tangier in March and departed later that month for Marrakesh, bearing a letter from the Spanish monarch to the sultan. The consul recommended him to the "Minister Effendy" 89 while reminding him of his debt incurred in Spain, though he doubted it would be paid:

I gave him a hint about the six hundred pesos fuertes that, by arrangement with Your Excellency and by order of His Majesty, we loaned him in Madrid; and he suggested that either after seeing the king his master or after returning home to Rabat he would be in possession of that sum. I doubt that is so, because I have heard, as I told Your Excellency in my

87 González Castrillo, El viaje, 81 .

88 Count Floridablanca to J.M. González Salmón, El Pardo, 26 January 1787. Letter from the king of Spain to the sultan of Morocco, dated in El Pardo on 26 January 1787. The Moroccan's receipt dated 13 January 1787: AHN, Estado, leg. 4316. El Pardo to J.M. González Salmón, 16 and 26 January 1787, AHN, Estado, leg. 4319.

89 He hoped to have the sultan act "while ignoring any negative report he may have received about the conduct of Ben-Abdelhadi as to his dealings in Malta and the lengthy time he has spent on this commission": J.M. González Salmón to Count Floridablanca, Tangier, 12 March 1787, AHN, Estado, leg. 4319. 
letter No. 53, that he is very short of funds; and lately I learned that he incurred other debts in Spain, with the Venetian Ambassador in Madrid and with certain individuals in Cádiz, which makes it unlikely he can repay them all. Therefore I ask you if I should proceed against this Moor in some way in case he delays his repayment of those six hundred duros. ${ }^{90}$

Al-Hadi emerged successful from his audience with the sultan and returned to Tangier, where he turned over to the Spanish consul a Canary Island sailor who had been arrested for smuggling wax in Mogador. As a result the order came from Madrid "not to press this individual for the twelve thousand reales that were lent him here by order of the king our master, but rather to wait for him to repay them honestly" 91

In May 1788 al-Hafi was in Tangier, about to embark on another embassy; he asked the European consuls there to charter him a ship for Cádiz, but was denied. He therefore went to Tetouan and boarded a Ragusan ship bound for Malta. ${ }^{92}$

\subsubsection{Allal al-Awdi and Qaddur al-Awdi (1784)}

These two alcaides and uncles of the sultan went on pilgrimage to Mecca in 1783 , and the sultan took advantage of their journey to send a fine gift to the caliph in Istanbul. He also charged them with stopping in Malta to reimburse

90 "[L]e insinué algo sobre los Seiscientos Pesos fuertes que por disposición de V. E. y de orden de S. M. se le prestaron en esa Corte y me ofreció, que bien después que vea al rey, su Amo, o regresando á su Cassa de Rebat, dispondrá el abono de esta cantidad. Aun dudo lo compla asi porque tengo noticia como he dicho a V.E. en mi Carta ${ }^{\circ} 53$ se halla mui limitado de facultades, y últimamente he sabido que ha contrahido otras deudas en España, con el Embaxador de Venecia en essa Corte, y algunos sujetos en Cadiz, lo que precisamente hace mas difícil la satisfacción de todas, y asi deseo saber de V. E. si he de tomar algun recurso contra este Moro en caso que retarde el pago de los citados Seiscientos Duros." He arrived in early March on a Ragusan ship: J.M. González Salmón to Count Floridablanca, Tangier, 12 March 1787. The Secretariat of State understood that the debt would not be paid: Aranjuez to J.M. González Salmón, 15 May 1787, A HN, Estado, leg. 4319. In April the consul took up the matter again: "I greatly doubt that this Moor will replay the twelve thousand reales de vellón that His Majesty ordered and Your Excellency arranged for him to be loaned in Madrid; for according to my information he is a ruined man who does not even have food to eat in his house in Rabat": J.M. González Salmón to Count Floridablanca, 16 April 1787 . In May the sultan was still demanding to see his ambassador, who had not yet appeared before him: translated letter from the sultan to J.M. González Salmón, 22 Ma7 1787, A HN, Estado, leg. 4319.

91 J. M. González Salmón to Count Floridablanca, Tangier, 30 June and 10 July 1787, AHN, Estado, leg. 4319 . On his missions see Arribas Palau, "El marroquí Muhammad b. 'Abd al-Hadi." 
several Maltese who years before had been seized out of a Ragusan ship; their recompense was 383 bags of wax that weighed 509 quintales. ${ }^{93}$ They sailed in November of that year from Tangier with a large retinue in a felucca of the Spanish monarch under Officer Rentas's command, bound for Cádiz; but "they were not very satisfied with the felucca, for they had expected a vessel of a higher rate to fetch them. ${ }^{94}$ In Cádiz they collected the sum that the sultan had deposited there for a failed rescue of Muslim slaves in Malta. ${ }^{95}$ They were among the few ambassadors who, having stopped at a Spanish port, were actually able to reach Madrid, as Floridablanca told the Spanish consul in Tangier:

These two Moroccan alcaydes did not travel straight from Cádiz to Cartagena, as the king had instructed; though this was suggested to them they would not agree to it, insisting in traveling to the court. They duly arrived here and have been treated with all proper distinction: the king granted them an audience and received them in the kindest way, assigning them a daily sum for their sustenance, a carriage from the royal stables, and a comfortable house. ${ }^{96}$

From the capital they proceeded to Cartagena, arriving in February $1784^{97}$ Great efforts were made to give them comfortable accomodation:

The king had ordered that they be welcomed and treated according to their rank, so that the commandant of the Department found great

93 Arribas Palau, "Sobre seis malteses."

94 They appear in the sources also as Al.lel and Caddor El Udiy: J.M. González Salmón to Count Floridablanca, Tangier, 19 November 1783, AHN, Estado, leg. 4317. Also as Ali-elKador and Ben Hudy: Martínez Rizo, Fechas y fechos, 1:57.

95 Arribas Palau, "Rescate de cautivos musulmanes en Malta."

96 "Estos dos Alcaydes Marroquíes no pasaron en derechura de Cádiz a Cartagena como el Rey había dispuesto. En efecto aunque se les hizo esta insinuación no convinieron ello insistiendo en pasar a la Corte. Han llegado pues a ella, y han sido tratados con toda distinción, haviendoles admitido el Rey a una audiencia, recibiéndoles con el mayor agasajo, y habiéndoseles señalado un diario para su manutención, un coche de las Reales Caballerizas y una casa acomodada": Count Floridablanca to J.M. González Salmón, 29 December 1783, AHN, Estado, leg. 4316.

97 On their arrival in Cartagena on 4 February they are called Ali-el-Kador and Ben Hudy, relatives of the king of Morocco: Martínez Rizo, Fechas y fechos, 1:57. They wrote two letters from Cartagena that in the opinion of the translator Miguel Casiri "are not translated because they contain nothing of interest for the court ... these two letters are in very poor handwriting and are almost illegible": note by Casiri appended to the letter from J.M. González Salmón to Count Floridablanca, Tangier, 11 March 1784, A HN, Estado, leg. 4317. 
difficulty in locating a lodging for them; but fortunately Don Juan Antonio Torreblanca, the administrator of salt and tobacco, was absent on leave and the ambassadors were put up in his house, which was spacious and comfortable. The ambassadors had with them a suite of fifteen persons. On their journey from Madrid to this city they spent twenty-five thousand reales charged to the state, plus forty-five thousand in their eighty days in Cartagena. They were carrying more than two million reales as a gift for the sultan. ${ }^{98}$

The Moroccans were not satisfied, however, because all their requests were not granted: "The commandant of the Department, though he had orders from the king to welcome the ambassadors, thought that what they asked was excessive and denied them, leaving them very unhappy":

In spite of having incurred expenses from the state of seventy thousand reales between their journey from Madrid and their stay in Cartagena, and having been provided for their voyage to Constantinople with four sugarloaves, two quintales of white biscuit, four large baskets of oranges and lemons, six dozen hens, six sheep, twenty-four varas of blue fabric of Spanish make, eight lengths of gray fabric and ten of fine Brittany linen, they also requested seven varas of red fabric, seven of media [?] of the same, one pound of gold thread, ten varas of crimson damask, and thirty-six of velvet of different colors. ... To the gifts that the squadron was taking to the caliph from His Majesty were added in Cartagena four ships' captains and ten Turks who had been slaves in this arsenal. ${ }^{99}$

98 "Estaba mandado por el rey que se les agasajara y tratara con arreglo á su rango, con cuyo motivo el comandante general del Departamento se vió en el mayor apuro en buscarles alojamiento; pero afortunadamente se hallaba ausente con licencia el administrador de las sales y tabacos D. Juan Antonio Torreblanca, y fueron alojados los embajadores en la casa de éste que era espaciosa y cómoda. Dichos embajadores llevaban consigo una comitiva compuesta de 15 personas. En el viaje de Madrid á esta ciudad hicieron de gasto por cuenta del estado 25.00o reales, y 45.00o en los 8 o días que permanecieron en Cartagena. Llevaban de regalo para el sultán mas de dos millones de reales": Martínez Rizo, Fechas y fechos, 4 February 1784, 1:57.

99 "No obstante haber hecho de gastos por cuenta del Estado 70.00o reales entre su viaje desde Madrid y estancia en Cartagena y haberlos provisto de viaje á Constantinopla de 4 pilones de azúcar, 2 quintales de galleta blanca, 4 serones de naranjas y limones, 6 docenas de gallinas, 6 carneros, 24 varas de paño azul de fábricas españolas, 8 piezas de medio color y 10 de Bretaña, pidieron aun 7 varas de grana, 7 de media id, una libre de hilo de oro, 10 varas de damasco carmesí y 36 de terciopelo de diferentes colores. ... A los regalos que la escuadra llevaba al gran señor de parte de S.M. se añadió en Cartagena 4 arraezes 
The two men finally left the city for Istanbul in May 1784, sailing in a fleet of Spanish warships under the command of Gabriel de Aristizábal. ${ }^{100}$

As happened with most of the Moroccan envoys who passed through Spain, the letters that these two sent during their journey to the governor in Tangier reached him through Spanish authorities, who were thus informed of the content of the correspondence. ${ }^{101}$ The man who had interpreted for the two men returned to Tangier:

The Moorish interpreter who went with the Alcaydes Al-le and Caddor el Uddy has arrived in this [city] from Cartagena; he comes proclaiming the fine treatment they received in that court, as in the other places that they passed through. ${ }^{102}$

\subsubsection{Muhammad b. Abd Allah al-Zuwayin (1789-179o)}

This brother-in-law and right-hand man of Muhammad Ben Abdallah, known to Spaniards as Mohamed Essuin, took advantage of an embassy to Istanbul to make the pilgrimage to Mecca with members of his family. ${ }^{103}$ He returned from the Ottoman capital in the Spanish war frigate La Soledad, which took him to Cádiz; he was afraid of not being received by the new Moroccan Sul$\tan$ Muley al-Yazid. ${ }^{104}$ He was dissuaded from traveling to Madrid, so as not

y 10 turcos que estaban esclavos en este arsenal": Martínez Rizo, Fechas y fechos, 24 April 1784, 1:175.

100 Consisting of the ships of the line Triunfante and San Pascual, the frigate Santa Clotilde, and the brigantine Infante: González Castrillo, El viaje.

101 J.M. González Salmón to Count Floridablanca, Tangier, 27 July 1784, AHN, Estado, leg. 4317.

102 "Ha llegado a Esta de la de Cartagena el Ynterprete Moro que fue con los alcaydes Al-le y Caddor el Uddy, quien se viene haciendo lengua del buen trato que se les ha dado en essa Corte, como por los demás sitios que han transitado": J.M. González Salmón to Count Floridablanca, Tangier, 13 May 1784, A HN, Estado, leg. 4317.

103 The ambassador was accompanied by "a retinue of twenty-four and nine women, five of whom are Georgians he brought from Constantinople, apparently at the request of the late King of Morocco": Count Floridablanca to J.M. González Salmón, 15 June 179o, AHN, Estado, leg. 4316. He sailed for Rabat "with his wives and retinue" in a ship belonging to the commercial house of Benito Patrón, which held the monopoly on exporting grain from Dar al-Beida: J.M. González Salmón to Count Floridablanca, 13 July 179o, A HN, Estado, leg. 4313 .

104 Aranjuez to J.M. González Salmón, 6 July 179o. The Spanish consul worried that the ambassador's delay in Cádiz might cause him problems with the new Moroccan monarch: "It would be unfair if Essuin, to excuse himself, laid the blame on us; [we urged him to stay] only to do him a favor and fulfil his wishes": J.M. González Salmón to Count Floridablanca, Tangier, 19 July 179o, AHN, Estado, leg. 4313. 
to arouse further doubts. After a few days he was given passage to Tangier in a different Spanish frigate. ${ }^{105}$ Consul Juan Manuel González Salmón presented the following bill, at a rate of five hundred reales per day:106

TABLE 4 Expenses incurred by Essuin in Cádiz, 5 June-9 July 1790

\begin{tabular}{lrc}
\hline Item & Reales & Maravedís \\
\hline Maintenance & 17,500 & \\
Food & 2,990 & 24 \\
Payments to Bigga & 3,530 & \\
Provisions for return journey & 7,057 & 32 \\
Lodging & 1,665 & \\
TOTAL EXPENSES & 32,743 & 22 \\
\hline
\end{tabular}

The seventeen thousand five hundred reales or 875 pesos fuertes were paid by Guillermo Coronata, a diplomatic agent and merchant. ${ }^{107}$ To the sum above must be added another hundred pesos fuertes paid to the ship's captain and first mate, so the total reached 35,283 reales and twenty-two maravedís. Essuin was not satisfied, and according to Consul J.M. González Salmón asked several times that the daily sum assigned to him be raised. ${ }^{108}$

105 J.M. González Salmón to Count Floridablanca, Tangier, 10 and 13 July 179o, AHN, Estado, leg. 4313 .

106 His maintenance consisted of payments of five hundred reales a day for thirty-five days, adding up to 17,5 oo reales or the equivalent of 875 pesos fuertes. Guillermo Coronata supplied him with food for another 2,99o reales and 24 maravedís. His supplies included oranges, wax, lemons, raisins, cherries, walnuts, candied pumpkin, syrup, horchata [a drink extracted from tiger nuts], coffee, sugarloaves from Hamburg, semirefined sugar, Seville olives, Flemish lard, six sheep, one calf, chairs from Holland, and a new bed with mosquito netting. The rent for the house Essuin occupied came to 1,665 reales and his provisions for the journey from Cádiz to Rabat, 7,065 reales. The Moroccan Bigga was paid 176 pesos fuertes and 10 reales on Essuin's instructions. In addition, Captain Hamsaly and the interpreter were paid 2,540 reales: J.M. González Salmón to Count Floridablanca, 13 July 1790, AHN, Estado, leg. 4313.

107 He was a Genoese in service to Spain, as shown by several payments he received from the Spanish government in the last decade of the eighteenth century.

108 J.M. González Salmón to Count Floridablanca, 13 July 179o, A HN, Estado, leg. 4313. 
As we already mentioned in this chapter, Spain assumed such costs in the hope that those who benefited would become defenders of Spanish interests in Morocco. As the consul general in Tangier put it,

That Moor departed very happy, and promising to give proof of his gratitude in promoting affairs of ours with his sovereign, because of the special care I took to favor him throughout his residence here. I even gave a dance for him that pleased him very much, for the brilliance of those who attended and because he had never imagined that the ladies of Spain could act in such a delicate and friendly manner. In short, I am persuaded that the thirty-five days he spent in this [city] will prove very useful in leading him to form a better image of the Spanish nation than the one he held up to now. ${ }^{109}$

Spain's hopes were thoroughly dashed, however. Al-Zuwayin fell out of favor with the new Sultan al-Yazid (1790-1792), who ordered him executed; one of his hands was cut off and nailed to the door of the Spanish consul's house in Tangier. This incident, together with the attacks on Ceuta, was one of the Spanish Crown's chief motives for declaring war on al-Yazid. ${ }^{110}$

\subsubsection{Assan Aga Giritri (1791)}

In April 1791 the Spanish consul in Tunis, Manuel Ventura Buzarán, landed in Barcelona accompanied by Assan Aga Giritri, who claimed to be the ambassador from the Sublime Porte to the sultan of Morocco; his son and four other persons came with him. Buzarán requested a ship at royal expense to convey them to Morocco, but the Captain General of Catalonia refused

because I have received no order about it, and considering the fact that the envoy's business bears no relation to our court and is unconnected to its political affairs. And I told him that he would receive the help needed

109 "Dicho Moro ha ido sumamente gustoso y prometiendo dar pruebas de su gratitud en los asuntos que nos pueda servir al lado de su Soberano por el particular esmero que he tenido en obsequiarle todo el tiempo de su mansión aquí, pues hasta le di un Baile que le agradó mucho, por el concurso tan lucido que hubo, y porque nunca se había figurado que las Señoras de España tuviesen un trato tan fino y amable, en fin me persuado de que los 35 dias que ha estado en esta servirán de mucho, para que forme de la Nacion Española mejor idea que ha tenido hasta ahora": J.M. González Salmón to Count Floridablanca, 13 July 1790, AHN, Estado, leg. 4313.

110 Carmona Portillo, Las relaciones hispano-marroquíes. 
to allow him to embark, and passage if the envoy paid for it with his own money, or if Buzarán assumed responsibility.

Assan Aga protested, believing that Buzarán had assured the Bey of Tunis that he would convey him to Tangier or Tetouan. He began a long and bitter dispute with Buzarán:

\begin{abstract}
[Assan Aga] claimed that by order of the Bey of Tunis, [Buzarán] had committed himself to convey him with his retinue until they reached Tangier or Tetouan. And Buzarán denied such an obligation, as we conclude from Witness Statement No. 1, which I include so that Your Excellency may learn of the efforts I ordered made in the matter. I also report that in consequence it was suggested to the Mohammedan that without withdrawing his claim against Buzarán (about which he was given a witnessed copy) he could engage a vessel for his journey on his own; and he promised to do so without delay, for which he has already tried to arrange it with a French captain who was about to leave this port. ${ }^{111}$
\end{abstract}

At Floridablanca's urging the Captain General agreed to transport Assan Aga to Morocco at the expense of the Royal Treasury, then notified both sides in the dispute of "the king's beneficence." Later he ordered that the ship in question set sail, but was ignored because the French captain had to "fill his cargo hold along the way." Another ship was sought to transport "the Ottomans":

When [the envoys] learned of the king's decision to convey them to Morocco at his expense, they then demanded that [the Spanish] should also

111 “...[P] sin relación alguna con nuestra Corte, é inconexo enteramente con sus asuntos Politicos, y le manifesté que tendría los auxilios conducentes á facilitar su embarco y pasage pagándolo el enviado de su dinero, ó tomándolo Buzarán a su Cargo.” “...[P]retendiendo aquel que con intervención del [B] ey de Tunez se havia obligado este a hazerle transportar con su Comitiva hasta ponerlos en Tanger, ó Tetuan, y negando Buzarán semejante obligación según resulta del Testimonio $\mathrm{N}^{\circ} 1$ que incluyo para que V.E. se halle instruido de las diligencias que mandé practicar en su razon, haciendo también presente, que en virtud se intimó al Mahometano que sin perjuicio de reclamar su derecho contra Buzaran (para lo qual se le dio copia testimoniada que pidió) diligensiase embarcación con que hir a su destino por su cuenta, y prometió executarlo sin demora a cuio fin trató ya de ajustar con un Capitan Frances que devia salir en breve de este Puerto." On 16 April 1791 Count de Lacy wrote to Count Floridablanca, "Assen Aga was a Turk, Assen Aga and his family, Morocco, 1791. A commissioned Turk recommended by the Bey of Tunis who became an agent or consul of Morocco in Candia": AHN, Estado, leg. 5803, Exp. $5^{2}$ (54). 
pay for the cost of their lodging and board in one of the inns of this city. They presented a very inflated bill from the innkeeper, which I did not accept for lack of an order authorizing me to pay their expenses; nor did Buzarán, who was in charge of transportation costs, wish to attend to the demand of the inn's people. We decided that the bill for the inn was due to them alone, and therefore he went to the Turks' lodging to tell them that their conveyance to Morocco was already ordered by the king and he was able to pay only that, and no other expense. ${ }^{12}$

At this point Vicente Bronza, who administered the Porte's commercial affairs in Barcelona, ${ }^{113}$ intervened in defense of Assan Aga, giving rise to tense exchanges with Buzarán:

The Mohammedans took the case as an insult and offense to their personal character and also to one entrusted with Turkey's commercial affairs. And they presented me with the complaint that goes at the head of the documents included in Witness Statement No. 2, demanding immediate satisfaction from me; and if not they would send an express to the court to obtain it and remain here until they received a reply.

The Captain General, faced with an affair he considered "serious" and because the monarch had questioned Buzarán's role, decided that the latter fell outside his jurisdiction. Determined that the conflict should not escalate, he agreed to all of Assan Aga Giritri's demands, believing that his remaining in Barcelona would only generate even greater costs:

112 "Sabedores estos de la resolución del Rey, para que se les condujese a Marruecos de su cuenta, entraron en la pretensión de que se les pagase también el coste de la detención, y subsistencia en esta Plaza en una de sus Fondas, presentando la cuenta del Fondero mui subida, en que no creí deber tomar parte careciendo de orden que me autorizase al abono de gastos, ni Buzarán encargado de los del transporte quiso prestarse a la solicitud de los de la Fonda, fundamos en que la suya se ceñia solamente á aquellos, y en este concepto pasó a la Posada de los Turcos a manifestarles que su conducción á Marruecos era ya mandada costear de cuenta del Rey, y la que unicamente havia facultades de pagar, y no otro gasto."

113 As we stated in the Introduction, we shall not discuss the ambassadors, envoys, consuls, or other non-Muslim subjects sent by caliphs, sultans, deys, or beys to Spanish soil. We shall do so only to the extent that they appear related to Muslim subjects in the problems that the latter encountered or created. 
[Because] retaining the Turks in this port would cause increased expense, new difficulties that would delay their departure, and perhaps greater harm through daily incidents, I called them into my presence. And when several observations I made to them - that the offense was to Bronza, not to their character; that Buzarán was not my subject, so they must appeal to the king to decide the case - proved useless in changing their minds, I proposed that we would gather summary information about the case, tell them the conclusions, provide a ship to transport them to Morocco, and pay the costs of their residence in this city, all at His Majesty's expense, if they would take ship for their destination without further delay.

The supposed ambassador appeared satisfied, so the Catalan captain Josep Valenty was engaged to take them to Tetouan or Tangier in his pink San Francisco de Paula, which was

of more than usual capaciousness, with six cabins for the respective accomodation of the envoy, his son, and the four members of his suite ... plus their maintenance in decent style with the provisions that the captain pledged to take on.

In spite of this agreement, however, the Captain General reported that Assan Aga tried to obtain even greater benefits from the situation:

The Turks have tried again to have us cancel [the agreement], give them the ten thousand reales promised to Captain Josef Valenty, and let them find their own ship. But refusing such an improper and self-interested request, I have determined that they should embark this evening in the ship already prepared, which will set sail for its destination tonight without fail; for which I have warned the Turks in advance and made the necessary arrangements.

The Captain General attributed much of the problem to the machinations of the commercial representative Vicente Bronza and a Venetian captain and interpreter named Juan Morin who worked with him. Both had behaved badly in the past: in the suspicious shipwreck of the polacre La Gasparina off Cadaqués in January 1787 , during which some Jews who had sailed in it from Algiers were robbed:

Both are bad men and have influenced the Turks by always being near them and sharing their table. And since Your Excellency may take 
measures against Bronza based on the reports you requested and I have provided, I am of a mind to take them also against Morin and order him out of this city, if the information I am seeking about his conduct gives sufficient reason to do so. ${ }^{114}$

The Captain General, however, believed that the greatest responsibility fell on Buzarán and his "thoughtlessness":

For he brought the Turks to this port, making a detour from the normal direction of their journey and route; and probably, as can be inferred from the insistence and demands of the Ottomans, he offered them aid that could not and should not be given and was not within the power of agents who are independent of the business of our government.

114 "Los Mahometanos tomaron el caso en clase de agravio y ofensa a su carácter como hecha en su presencia, y a un encargado de los Negocios de Turquia, y me presentaron el Recurso que bá por Caveza de las diligencias comprehendidas en dicho Testimonio de $\mathrm{n}^{\circ} 2$ pidiendome pronta satisfaccion, y si no que despacharían expreso a la Corte para conseguirla, permaneciendo hasta su respuesta." “...[L]a mayor detención de los turcos en esta Plaza originaria dispendios mas crecidos, nuevas dificultades que atrasasen su salida, y quizás perjuicios de mayor monta por las ocurrencias del dia, los hice comparecer en mi presencia, y después de haver sido inutiles para que cediesen de su pretensión varias reflexiones que les hize, sobre que el agravio, si lo hubo, fue á Bronza, y no a su Carácter, y que Buzarán no era Subdito mio, y que por consecuencia era indispensable acudir al Rey para la decisión del caso, entré a proponerles que se reciviría Ynformacion sucinta del hecho, se les daría testimonio de su resultancia, se les havilitaria Barco para su transporte a Marruecos, y se les pagarían los gastos de su mansión en esta ciudad todo de cuenta de S.M. embarcándose luego para su destino sin mas espera." “...[D]e mas que regular capacidad y con seis camarotes para el correspondiente alojamiento del enviado, de su Hijo, y de los quatro de su Comitiva ... inclusa la manutención con la decencia que manifiestan las provisiones á que se ha obligado el Patron." “[S]e ha intentado nuevamente por los Turcos que se anulase, y se les dejase libertad de buscar Barco por si, entregándoseles los Diez mil reales en que estaba ajustado el Patron Josef Valenty, pero despreciando solicitud tan impropia e interesada, hé resuelto que embarcándose oy en el Buque que está dispuesto, se haga esta noche á la Vela sin falta para su destino, para lo qual hé hecho avisar con tiempo á los Turcos, y estan dadas las providencias necesarias." "Ambos sujetos son malos y los que han influido á los Turcos, estando siempre a su inmediación, y aprovechando su Mesa, y siendo verosímil que V.E. por los informes que me pidió, y he dado, tome providencia sobre Bronza, estoy en animo de tomarla Yo igualmente con Morin, mandándole salir de esta Ciudad, si las averiguaciones que estoy determinado á hacer acerca de su conducta dan suficiente motivo a egecutarlo." In particular, he accused Morin of the "suspicious shipwreck that occurred in the month of January 1787, off the coast of Cadaqués, of the polacre La Gasparina of which he was captain, and of the robbery committed on it of some Hebrews who were aboard, coming from Algiers": Count de Lacy to Count Floridablanca, Barcelona, 16 April 1791, AHN, Estado, leg. 5803, Exp. $5^{2}$ (54). 
He concluded his report by arguing that he had acted as he did because the affair, by its nature and circumstances, was one

that I cannot view with indifference and leave to chance, so as not to compromise the political alliances that the crown has formed, and not to endanger the effects of those being negotiated now. ${ }^{115}$

He therefore hoped that his management of the affair would be approved and that he would be compensated for the 16,948 reales de vellón and 20 maravedís that he had spent on maintenance and charters. His petition received a favorable reply. ${ }^{116}$

Manuel Ventura Buzarán, for his part, gave a statement before the king's notary in Barcelona that contained his own version of the events:

The Bey of Tunis and his Prime Minister, when I was about to leave that kingdom, requested that, since His Majesty's courier xebec was empty of cargo and I would be sailing in it, passage be arranged if it were not inconvenient for the Turks Assen Aga Vekil, consul of the Emperor of Morocco in Candia, a son of his, and six servants, who were going to Morocco to kiss the hand of the new Emperor. Their petition was granted in order to please them, though they have caused great difficulty. When it was asked what should be done with those Turks once we arrived in the Peninsula, the Prime Minister replied categorically that their passage was requested only as far as my intended port, but that from there on they must plan to assume their own expenses until they arrived at their destination.

115 “...[Q]ue trajo a los turcos á esta Plaza, desviándolos de la regular dirección de su viage y ruta, y que probablemente, según se infiere del empeño y solicitud de los Otomanos, les facilitaría auxilios que no podía, ni devia, ni correspondían a unos Comisionados independientes en su cargo de los negocios de nuestro Gobierno." "[N]o he podido mirar con indiferencia y abandonar a la suerte, a fin de no comprometer los enlaces políticos que tiene contraídos la corona, y no aventurar los efectos de los que se tratan en el dia": Count de Lacy to Count Floridablanca, Barcelona, 16 April 1791, AHN, Estado, leg. 5803 , Exp. 52 (54).

116 "An account of the costs that the Turks Assen Aga and family incurred in the inn called El Escudo de Francia between 23 March and 16 April. They were 646 libras and one real de ardite, equivalent to 6,948 reales and 20 maravedís de vellón": a receipt from the innkeeper, Santos Sascali, for that sum, Barcelona, 16 April 1791. The remaining costs came from chartering the ship from Captain Josef Valenty, who was to provide Asan Aga and his company with food: Barcelona, 14 April 1791. The bill was to be presented to the Admiral: draft to the Count of Lerena, Aranjuez, 29 May 1791, AHN, Estado, leg. 5803, Exp. $5^{2}(54)$. 
He added that the Bey of Tunis had given him a sum equal to 230 pesos fuertes for his expenses, of which he had not spent any. On arriving in Barcelona the Turks thanked him for his services ("they gave me many thanks for the attentions and favors") and began searching for a ship to take them to some Andalusian port, so as to continue to Morocco from there,

paying the charter fee and any expenses involved. But after having landed they changed their whole way of thinking, for not only does it annoy them to pay a charter for Málaga or Algeciras but they want us to charter a vessel at His Majesty's expense to go directly to Mogador, and to cover all their costs already incurred and those they will need to pay until they reach their destination. I have told them many times that I am not authorized to grant them what they ask; they think that I do not want to do it, and keep insisting on their request. Their obstinacy has put me in the position of turning to Your Excellency so that in view of what I have explained Your Excellency may kindly take the measures you think most convenient. ${ }^{117}$

Assan Aga Giritry presented a report that offered his version in turn, introducing himself as "Azanaga Giritry, ambassador of the Great Lord." He added that he had left Istanbul on a Ragusan ship, chartered "at a certain amount per month," carrying a firman for the Bey of Tunis. He presented the firman to the

117 "El Bey de Tunez y su primer Ministro pidieron por favor quando yo estaba por salir de aquel Reyno que pues el Jabeque Correo de Su Magestad estaba en lastre, y que yo debía venir en el, se facilitasse el Pasage, si no incomodaba, a los Turcos Assen Aga Vekil, ó Consul del Emperador de Marruecos en Candia, a un Hijo suyo, y seis criados, que iban a Marruecos á besar la mano al nuevo Emperador; Se adherió a su solicitud por complacerlos, aunque han incomodado muchissimo, y haviendoseles preguntado que se debería hazer con los dichos Turcos quando llegásemos a esta Peninsula, respondió cathegoricamente el primer Ministro, que solo pedían se les diesse el Pasage hasta el Puerto donde yo llegase, pero que de allí adelante era menester que pensasen ellos en hazer sus gastos hasta llegar a su Destino." “...[P] agando el flete y gastos que se les ofrecieren, pero después de haver venido a tierra ha[n] cambiado todo su modo de pensar pues no solo no les acomoda el pagar el flete para pasar á Malaga ó Algeciras, sino que quieren que se les flete un Bastimento por cuenta de su Magestad para hir en derechura á Mogador y que se les paguen todos los gastos hechos, y los que necesiten hazer hasta llegar a su Destino; les he dicho repetidas vezes, que no tengo facultad para concederles lo que solicitan; crehen que yo no quiero hacerlo, é insisten siempre en su pretensión; Su obstinación me ha puesto en la precisión de recurrir a V. Ex ${ }^{\mathrm{a}}$ para que en vista de lo espuesto, se sirva V. Ex $x^{\mathrm{a}}$ tomar la providencia que tuviese por mas conveniente": Félix Alberto Nogues, royal and public notary in Barcelona, witnesses the declaration of Manuel Ventura Buzarán, Barcelona, 29 May 1791, AHN, Estado, leg. 5803, 52 (54). 
Bey, but was bearing another for the "Emperor of Marocho [sic]"; since it was winter and the roads were bad he he had decided to travel to that country by sea. The Tunisian ruler then decided to send him in a Spanish vessel, docked at Bizerte, that was preparing to take the Spanish consul, Ventura Buzarán, to Cádiz; since it would be crossing the Strait it could let him off at Tetouan or Tangier. Assan Aga accepted the offer, requesting that

he be given a document promising that it should be done; but he was told that he would not need it, especially since the abovenamed secretary would be aboard. And this was why the petitioner declined to accept another ship of greater quality and comfort that was in Bizerte and which the secretary had offered him, [pledging to] pay the charter fee besides, because he did not wish to depart from what the Bey of Tunis had decided. He embarked, and seven days later the ship reached the port of Majorca, where they served the quarantine, after which the journey continued in the direction of Gibraltar. And on the third day, when they were windward of the island of Ibiza, the secretary told him that the wind was contrary and that, being unable to continue the journey, they must come to this port of Barcelona. He added that he would help [Assan Aga] to find a ship in this port, from which he would be able to continue traveling to his destination.

Two days after they reached Barcelona, Ventura Buzarán announced that he had found a ship but that Assan Aga would have to pay to charter it. The Turk did not agree and asked for a document to witness the decision, but Buzarán declined to give it. Asan Aga argued that he should "give proof to the Great Lord of the detour he had suffered in his voyage and the delay in fulfilling his duty, and also to undertake as soon as possible the continuation of his journey to Morocco." He therefore asked the Captain General himself to provide a document that would explain why the ship had docked in Barcelona instead of taking him to Cádiz. ${ }^{118}$

118 “...[S]e le hiziese un papel de obligación de practicarse assi, y se le fue respondido que no lo necesitaba mayormente hallándose a bordo el Secretario referido, y este fue el motivo porque el Suplicante dejo de aceptar otra embarcación de mejor porte y comodidad que se hallaba en Biserta, y le ofrecia el Secretario pagando también los fletes, pues no quiso separarse de lo dispuesto por el Bey de Tunez. Se embarcó, y a los siete días llegó la embarcación al Puerto de Mallorca, donde se hizo la quarentena, después de la qual se emprendió otra vez el viage, tomando el rumbo hacia á Gibraltar, y el tercero dia hallándose en el Sobrevento de la Ysla de Iviza le dixo el Secretario que el viento era contrario, y que no pudiendo proseguirse el viage era preciso venir a este Puerto de 
At this juncture the political and military governor of Cádiz, Gerónimo Simón Mothezuma y Ahumada y Salcedo, opened an investigation on the assumption that Assan Aga was "the Ambassador of the Great Lord" or "ambassador extraordinary from the Great Lord to the Emperor of Morocco." It was decided that he should be assisted by Vicente Bronza, "Consul of the Ottoman Porte in this city, whom he presented as his interpreter," and by the Venetian Juan Morin. Morin translated "the Spanish language to the Italian one, which the Ambassador uses and understands, or to his countryman," while also rendering it "into the popular and native language of the Turkish ambassador, after a long conversation." 119

Assan Aga presented another statement insisting that Buzarán should charter him a ship or, if not, provide a certificate of his failure to do so. He again complained that instead of conveying him to Tangier or Tetouan Buzarán had taken him to Barcelona and had installed the Turks in

the inn on Calle Nueva without saying anything about who would pay for it, and finally presented him with the bill for his stay and that of his retinue. He says that because his voyage was delayed, he himself arranged a charter with the French captain Jaime Bernard of the brigantine L'Aimable, and it was then that Buzarán appeared to tell him that His Majesty had ordered that a ship be chartered for him at royal expense.

Assan Aga continued to insist that the full cost of his stay in Barcelona and his voyage to Tangier or Tetouan be paid. He claimed that Buzarán had promised him to provide whatever funds the king did not, but had then gone back on his word in a conversation in which only they two were present together with Vicente Bronza, and in which emotions ran high:

Buzarán grew extraordinarily heated, though [Assan Aga] had not failed to respect him as he deserved, to the point that he tried to throw a candlestick at the consul's head, bursting out in truly insulting words and making the improper gesture of putting his hand on his sword in the presence of this complainant, his son, and others who were with him, and making his voice heard throughout the house. This indecent action

Barcelona, añadiendo que el ayudaría a buscar embarcacion en este Puerto, y desde el se podría emprender el viage para su destino": Barcelona, 3 April 1791, AHN, Estado, leg. 5803, Exp. $52(54)$.

119 The parties appeared on 5 April 1791, although the text describing the event is dated 8 April 1791: AHN, Estado, leg. 5803, Exp. $5^{2}$ (54). 
justifies whether all this, and the details of what happened concerning the payment of his sustenance to the owner of the inn, can be related to Your Excellency if you wish. This incident, and the improper manner in which the said Don Manuel Ventura Buzarán has behaved, touch this complainant so closely that he cannot view them with indifference. And though he could easily put aside his personal interest, the truly scandalous nature and circumstances of the event call for satisfaction, even if it were not required by the fact that the injury or offense was done directly to a minister of the Ottoman Porte in this city, and if it were possible for the witness to ignore an event of this kind in the present case. The witness's honor is involved, and the fact that he was insulted in his own house, even his own chamber, constitutes an offense to his decorum and reputation.

Assan Aga therefore demanded that while his sustenance might be determined according to law, Buzarán must give him proper satisfaction; otherwise, "the complainant must be allowed to put his case before the throne in an express letter that he will send at his own expense to the Court for the purpose."120 The declaration by Bronza, "about thirty-eight years of age" and "consul of the Ottoman Porte in this city," was as follows:

120 “...[E]n la Posada de la calle nueva sin decirles nada sobre quien la pagaría, y finalmente se le presentó a el la cuenta de su estancia y de su comitiva. Ante el retraso en su viaje dice que el mismo buscó un flete con el capitán francés Jaime Bernard del bergantín L’Aimable, y fue entonces cuando Buzaran apareció diciéndole que SM había dado orden le fletase embarcación por cuenta Real." "[S]e enardeció extraordinariamente el citado Buzaran, sin que se le hubiese faltado al decoro que se merece, hasta llegar a querer arrojar por la cabeza de dicho Consul un candelabro, prorrumpiendo en palabras verdaderamente injuriosas, y haciendo el ademán irregular de poner mano á la espada en presencia del exponente, de su hijo, y de otros que le acompañaban, haciéndose además sentir por toda la casa: esta indecente acción, conforma si todo esto, y el por menor de lo que ha ocurrido en el pago de la manutención con el dueño de la citada Posada podrá hacerse constar a V.E. si lo estima conveniente. Este lance, y modo impropio con que se ha portado el referido don Manuel Ventura Buzaran ha tocado tan de cerca al exponente que no puede mirarlos con indiferencia; y ahun quando con facilidad podría renunciar a su interés propio, con todo su carácter, y las circunstancias verdaderamente escandalosas del lance exigen una satisfacción, quando por otra parte no la exigiese la de haverse directamente hecho la injuria ó ofensa a un Ministro de la Puerta Otomana en esta Ciudad, y le permitiesen al exponente sofocar en su instancia un hecho de esta naturaleza. El honor del exponente está comprometido, y la circunstancia de haverse insultado en su misma casa, y su mismo Aposento, hace que le haya ofendido su decoro, y su representación." Another report registered by Félix Alberto Nogues: No 2, Barcelona, 12 April 1791, A HN, Estado, leg. 5803, $5^{2}$ (54). 
While I was with this man [the ambassador] in his room at the lodging at eight-thirty in the evening of the 11th of this month, the aforenamed Don Manuel Ventura Buzarán appeared to discuss with the Ambassador whether he would or would not pay the cost of maintenance that the ambassador was incurring for himself and his family at that inn. And because Buzarán did not wish to pay for it, the Ambassador stated that he did not wish to take on payment for that expense, in the belief that [Buzarán] had told him that he would assume it, and that the innkeeper had been told of it so long as it did not exceed the usual and normal cost. But when in spite of this Buzarán insisted on what he had said, I intervened to tell him of the error he was committing, because he had told me himself, a few days after the Ambassador's arrival, that I should inform [Asan Aga] that if his maintenance continued the same he would pay for it, but that if they wished for anything extra they should pay for it from their own pocket. And I told him this politely in order to calm him and avoid resentment between the two of them.

He added that Buzarán had insulted him in a fury, declaring him to be

a trickster, a villain; but I, in spite of being thus insulted, replied to him mildly that he should be careful how he addressed me, because I had neither failed to respect him nor given him any reason [to do so to me], so he should be calm. This did not quiet him but made Buzarán even angrier, and gesturing with his hand as if to take up a candlestick he told me that if I did not be quiet he would throw it at me; at which I exclaimed, "You prick! ${ }^{121}$ It looks as if you have passed the limits of courtesy," and that is when he rose from his chair and put his hand on his sword as if he would draw it against me, uttering many words highly offensive to me: among others, that I was not fit to take off his shoes or to be his lackey. At this moment the ambassador got up and came with the others to restrain him and hold him back, which they managed to do, bringing an end to these excesses in the presence of the Ambassador, his son, their servant Ali, the interpreter Don Juan Morin, and the innkeeper Santos Sascelli. ${ }^{122}$

121 Cadzo, i.e. It. cazzo.

122 " $[\mathrm{H}]$ aviendome hallado con este en el mismo quarto de su Hospedage a las ocho horas y media de la noche del dia onze de los corrientes compareció el citado don Manuel Ventura Buzaran para tratar con el Embajador sobre si pagaría ó no el gasto de la manutención que el embajador por el y su familia estaba haciendo en aquella su Posada de suerte que no queriéndolo costear Buzaran, manifestó el embajador que no quería entrar en el pago de dicho gasto, supuesto que le tenia dicho que correría de su cuenta, y que assi lo tenia 
Juan Morin, aged thirty-one, testified that when Buzarán entered the inn and he witnessed the quarrel between him and Assan Aga "the aforesaid Bronza tried to mediate, and Buzarán grew enraged and made the gestures of throwing the candlestick at him and drawing his sword." Another witness was Assan Aga's son Ybrahim Aga, aged twenty-four and a native of Canea in Crete: he testified that Buzarán had offered to pay for their stay in Barcelona but that on the day in question he had come to the inn and told them he would not do it. Then they "exchanged some words, and since they were not speaking my language I did not understand what they said," though Ybrahim confirmed that Buzarán threatened to throw the candlestick and draw his sword. Ali Cará Mustafa Oglu, aged twenty-one and also from Canea in Crete, gave similar testimony. The latter two testified via the interpreter Juan Morin, who "has heard their oath according to the law and rite of their religion."123

The last to declare was Santos Sascelli, a Milanese aged thirty-four, the innkeeper of "El Escudo de Francia" where Assan Aga and his party had lived since 23 March. It appears that they were lodged on the orders of Buzarán, but "afterward he wished to withdraw from [the agreement], refusing to pay me." On the day in question he had heard raised voices in the room and a member of Assan Aga's party had called him in; he saw Buzarán shouting at Bronza and threatening to throw a candlestick at him and to draw his sword, "though I did not see that he actually touched it" - however, other people had been standing

advertido al mismo posadero mientras no se excediere de un gasto regular y ordinario, pero como con todo Buzaran insistió en su dicho, entré yo a manifestarle la equivocación que padecía por haverme dicho a mi mismo, al cavo de pocos días del arribo del Embajador que dixese a este, que continuando con el mismo trato de su manutención, se lo costearía, pero que si querían algún exceso, deberían pagárselo de su Bolsillo, y no obstante de haversele yo dicho con buen modo, para apaciguarle, y evitar que entre los dos, no hubiese resentimiento alguno. ... [Me llamó] un pícaro, un canalla, pero yo con todo de verme insultado de esta suerte le respondi con moderación diciendo que mirase como me trataba porque ni le perdia el respeto, ni le daba motivo para ello, lo que no le sirvió para moderarse, antes bien remontandose Buzaran mas en su cólera, y haciendo con la mano el ademan de querer agarrar un candelero, me dixo que si no callava me lo tiraría, mediante lo que me exclame diciendo, Cadzo, parece que Vm se pasa de los limites de la atención, y entonces fue, quando el, levantándose de la silla puso la mano en su espada, con ademán de quererla sacar contra de mi, profiriendo varias expresiones en mucho desprecio mio, y entre otras, que no era bueno para descalzarle el zapato, ni servirle de lacayo, sin que a este tiempo, levantándose el embajador acudió con los demás a detenerle y contenerle, como en efecto lo consiguieron, quedando aquellos excessos assi finalizados a presencia del mismo Embajador, del Hijo de este, de Ali Criado de los dos, del Ynterprete Don Juan Morin, y del Posadero Santos Salcelli": Auto, Barcelona, 15 April 1791, AHN, Estado, leg. 5803, Exp. 52 (54).

123 Auto, Barcelona, 15 April 1791, AHN, Estado, leg. 5803, Exp. $5^{2}$ (54). 
in between. He also testified that although Buzarán had indeed insulted Bronza and the latter had answered with "Cadzo," there was a nuance in that he had uttered "that term not in Buzarán's direction but from sheer wonder and astonishment at what was happening."124

A later report, unsigned but dated in June, explained that Assan Aga was actually "an agent or consul of Morocco on the island of Crete, who is on his way to Morocco to meet his new sovereign," and that Buzarán had escorted him "on the recommendation of the Bey's minister Mustafa Coggia." After they arrived in Barcelona on the courier xebec from Algiers, Buzarán had approached the Captain General to ask "whether he had to pay the costs he had incurred for them on the journey and also for their transport to Morocco; he was told that he did, and Count de Lacy was informed of everything." At that point, "the Turks being offended by this frivolous attitude of the king, they gave Count de Lacy so much trouble that he finally managed to send them off on a ship he chartered for them." The report criticized Vicente Bronza, "who acts as an agent of the Turks," and "a certain Juan Morin, a Venetian, both of whom are bad actors according to Count de Lacy," while censuring "some rash acts by Buzarán himself." But it also cast blame on the Captain General, who had facilitated the Turks' inflated rank by

allowing [Assan Aga] to be called envoy and Ambassador from the Porte to Morocco (on his own word and contrary to that of Buzarán) in the various declarations and legal statements that have been made in Barcelona. Because of this laxity it should be suggested to Count de Lacy that we avoid, on such occasions, becoming the object of ridicule by treating as Ambassador private persons and those of different types - which happened later in Almuñécar, where this Turk landed and was received as an Ambassador from the Porte (also on his own word and perhaps from some phrases in the documents he bore from Barcelona). There the commander at arms offered him all the honors he was able, based on this belief. ${ }^{125}$

124 Auto, Barcelona, 15 April 1791, AHN, Estado, leg. 5803, Exp. 52 (54).

125 “...[P] y Embajador de la Puerta a Marruecos en las varias declaraciones y diligencias judiciales que se han practicado en Barcelona: Sobre cuya facilidad parece convendría insinuar algo al Conde de Lacy para evitar que hagamos en tales ocasiones un papel ridículo tratando como Embajador á unos particulares y sujetos de distinta clase: lo qual ha sucedido después en Almuñecar donde ha tocado este Turco, tratandosele (también sobre su palabra y acaso por algunas enunciativas de los papeles que llevaba de Barcelona) como Embaxador de la Puerta, haciéndole el Comandante de aquellas armas, todos los obsequios que ha podido bajo este concepto": Unsigned memorandum dated June 1791. 
A marginal note on this document ordered that the Captain General of Catalonia be informed in writing, as was immediately done, urging him to put an end to the dispute and "conclud[e] any results that it could have had."126 But we have seen that the matter did not end there, because more detailed information arrived of Assan Aga's behavior in Almuñécar: he had introduced himself to the military governor of the port as "Ambassador or Minister of the Ottoman Porte assigned to Morocco." More precisely, the Captain General of the coast of Granada reported that

in Almuñécar this same Turk convinced the commander at arms that he was an ambassador or minister of the Ottoman Porte assigned to Morocco, and in this belief the commander offered him the appropriate honors and ceremonies. And perhaps the notion arose from some phrases in his charter with the ship's captain or other papers of ours that the Turk was carrying. I urge Your Excellency, by order of the king, to warn those responsible in the future that when some unknown personage arrives at any port in our principality, they make sure of his character and circumstances so as to determine the right way to address and treat him.

The document went on to say that no one should trust how persons who arrived in Spanish ports presented themselves "or depend on their word alone, especially when there are people worthy of trust who affirm otherwise." A later paragraph, which has been crossed out, reads:

As has happened in the present case, in which the Turk Assan, a mere agent or consul of the king of Morocco on the island of Candia, on his way to greet his new sovereign (according to the word of Buzarán, who must have known it), had the courage to call himself an envoy of the

A marginal note states that Lacy was informed of the matter in writing in June: AHN, Estado, leg. 5803, Exp. $5^{2}$ (54).

126 On what had occurred with "the Turk Assan Aga Giritri traveling from Tunis to Morocco, and with the agent Don Manuel Ventura de Buzarán among others, and Don Vizente Bronza, His Majesty approved Your Excellency's conduct in the manner of concluding any results it may have had. And His Majesty decreed that the 16,948 reales and twenty maravedís that were the total costs incurred by the Turk and his people be paid, including the charter for his passage to Tangier or Tetouan": Aranjuez to Count de Lacy, 8 June 1791, Estado, leg. 5803, Exp. $5^{2}$ (54). 
Porte; and we note how readily he was called that in documents of ours that have circulated in that city. ${ }^{127}$

In spite of the comic aspects of this episode, we should realize that such deceits and abuses were possible only the in context we have already described: the determination of Spanish authorities to prevent any minor incident from disturbing their relations with the Moroccan Empire and other Muslim countries. Aside from Buzarán's blunders and the credulity of local Spanish officials, it is clear that Assan Aga, like other servants of the Moroccan sultan, knew how to turn to his own advantage the weak points in the countries' bilateral ties, as we analyzed in Chapter 5 .

\subsubsection{North African and Ottoman Ambassadors}

Beside the Moroccan ambassadors who stopped over in Spain we must discuss the Maghrebi and Ottoman ones who did the same in the course of their diplomatic missions to third countries, especially to Morocco. In the cases we know of they did all they could to be received at the Spanish court, but were unsuccessful. The most prominent members of this group are several Turkish ambassadors and envoys to Morocco in the years 1785 to 1788 . The Ottoman Empire, having been forced to accept the Treaty of Kücük Kainarda (1774) and the later war between Austria and Russia (1787-1792), was keenly concerned with finding allies and supporters even in the western Mediterranean. ${ }^{128}$

\subsubsection{Haggi Ysmail Effendi (Morocco, 1785-1786)}

Around mid-1785 in Morocco a man named Haggi Ysmail Effendi claimed to be an ambassador from the caliph. The purpose of his mission is unclear, but

127 “...[E]l mismo Turco en Almuñecar, hizo creer al Comandante de aquellas armas que era un Embaxador ó Ministro de la Puerta Otomana destinado a Marruecos; y baxo de este concepto le hizo el Comandante los honores y obsequios correspondientes. Y por si acaso pueden haber dado motivo á este mismo concepto algunas expresiones de la contrata con el Patron de la embarcación ú otros papeles nuestros que llevase el Turco; lo expreso á V.E. de orden del Rey á fin de que prevenga a las personas á quienes corresponda, procuren en adelante, quando arrivase á ese ú otro puerto del Principado algún personaje desconocido, asegurarse bien de su carácter y circunstancias para arreglar el modo de nombrarle y tratarle. ... Como ha sucedido en el caso presente en que siendo el Turco Asan un mero Agente ó Consul del Rey de Marruecos en la Ysla de Candia que viene a conocer a su nuevo amo según ha asegurado el mismo Buzaran a quien debía constar ha tenido bastante valor para llamarse Enviado de la Puerta; notándose también igual facilidad en llamársele asi por nuestra parte en algunos escritos que se han extendido en esa ciudad": Aranjuez to Count de Lacy, 8 June 1791, AHN, Estado, leg. 58०3, Exp. 52 (54).

Bunes Ibarra, El Imperio Otomano, 203-26. 
it appears connected to the Ottoman policy of the 178 os that sought alliances and support in the western Mediterranean against the empire's enemies, particularly the Russians. Spain's vice consul in Tangier at the time, Antonio González Salmón, informed his superiors that Ysmail Effendi carried a letter from the Spanish representative in Istanbul and remarked on his "affability and good manners." 29 When Consul Juan Manuel González Salmón returned to his post in Tangier he met frequently with Ysmail Effendi, who explained that his principal charge was to solve differences between the Spanish and the Algerians and that once he achieved that he hoped to travel to the court in Madrid. ${ }^{130}$ The consul was enthusiastic about the Turk:

My conversations with the Turk Ysmael Effendi have pleased me greatly, because from his skill and efficacy in explaining himself I understood that the Sublime Porte is strongly determined to force the Algerians to make peace with us. And this person is eager to reach that Regency in order to settle these matters. He is very unhappy over having been delayed here, for he has told me that the caliph will assume that his mission to Algiers is concluded, something he plans to do on his way back to that court. ${ }^{131}$

The consul described the ambassador as a diplomat sincerely concerned to establish peace between Spain and Algeria and between both countries and Morocco, and also alarmed by the continued seizure of Spanish ships by corsairs of the Regency of Algiers. ${ }^{132}$ It does not appear that this ambassador's efforts bore much fruit. ${ }^{133}$ The Turk told the consul that he had asked permission from the Moroccan sultan to proceed to the Spanish court, but that the sultan had urged him to go to Algiers first to give the Dey his letters from the

129 Antonio González Salmón to his brother Juan Manuel, who was then in Cádiz: Tangier, undated but probably written in July 1785, AHN, Estado, leg. 4317.

130 J.M. González Salmón to Count Floridablanca, Tangier, 18 and 21 July 1785, AHN, Estado, leg. 4317 .

131 "La conferencia que he tenido con el Turco Ysmael Effendi me ha agradado mucho porque según el conato y eficacia con que se explicó, comprehendi que la Puerta Otomana está fuertemente empeñada en obligar a los Argelinos a que hagan la Paz con Nosotros, y este sugeto quisiera ya hallarse en aquella Rexencia para zanjar los asuntos. El se manifiesta bien desazonado por la detención aquí, pues me ha dicho que el Gran señor considerará ya evaquada su comisión de Argel, y que lo hará de camino para essa Corte": J.M. González Salmón to Count Floridablanca, Tangier, 27 July 1785, AHN, Estado, leg. 4317.

132 News of Ysmail Effendi's efforts in J.M. González Salmón to Count Floridablanca, Tangier, 3 August, 2 and 12 September, and 12 October 1785, AHN, Estado, leg. 4317.

133 J.M. González Salmón to Count Floridablanca, Tangier, 12, 19, and 27 October and 4 November 1785, AHN, Estado, leg. 4317. 
caliph; then from Algiers he could go "to Cartagena and continue to Madrid from there to conclude the peace [agreement]." 134 An interesting detail is that González Salmón told the Secretary of State that he had lent the Turk fifty pesos fuertes

to pay for the charter of the Ragusan ship that brought him here, because its captain would not accept Turkish money. I do not know if he will return them, but since this is the first such request I thought it convenient to oblige him in this small matter. ${ }^{135}$

Ysmail Effendi later showed his gratitude for the consul's favors, including the fifty pesos fuertes, which he planned to repay: "I shall never forget the many favors I received from you and the attentions you showed me."136 González Salmón replied urging him to "enjoy this small gift to the health of His Catholic Majesty."137 In April 1786 Ysmail Effendi was still in Morocco and the consul was trying to charter a ship to take him to Algiers. ${ }^{138}$ We do not know how Ysmail Effendi's Moroccan adventure ended or whether he was ever able to land in a Spanish port.

\subsubsection{Jamet Jaggi Effendi (Morocco, 1787-1788)}

An Ottoman ambassador, Jamet Jaggi Effendi, reached Mahón on Minorca in May 1787, having traveled from Istanbul by way of Toulon. He was accompanied by the Moroccan talbe Sid Casen Sayany 139 "and another Turkish individual, with fourteen more men, Moors and Turks, who belong to the retinue of

134 Ysmail Effendi to J.M. González Salmón, Tetouan, 14 November 1785, AHN, Estado, leg. 4317 .

135 “...para acabar de satisfacer el flete del Buque Raguseo que lo a conducido aquí, por que su Capitan no quiso tomar moneda turca. No sé si los volverá, pero por ser la primera vez que me ocupa me pareció conveniente servirlo en esta pequeña cosa." A second letter of the same date told Count Floridablanca that the consul had brought the Turk up to date on the difficulties of the negotiations with the Algerians, hoping the information would help him to act more effectively: J.M. González Salmón to Count Floridablanca, Tangier, 27 July 1785, AHN, Estado, leg. 4317.

136 Ysmail Effendi to J.M. González Salmón, Tetouan, 14 November 1785, AHN, Estado, leg. 4317 .

137 J.M. González Salmón to Count Floridablanca, 16 November 1785, A HN, Estado, leg. 4317.

138 On the events of February, J.M. González Salmón to Count Floridablanca, 27 February 1786. At the end of April a Ragusan ship came to convey Ysmail Effendi to Algiers: J.M. González Salmón to Count Floridablanca, 6 and 20 April 1786, AHN, Estado, leg. 4319.

139 Also Casei Shayany and Casen Sayany. 
the first two." ${ }^{140}$ From the island they embarked in the French brigantine Les Deux Amis under Captain J.B. Camoin, arriving in Tangier in June. They were obliged to serve a quarantine there, not having done so in any of their European ports of call. ${ }^{141}$ The Spanish consul wrote to the Secretary of State about two different men:

Both the Turkish envoy and the Ambassador of the same nation who is on his way to Morocco will return to this [city] to embark from its port. And it is said that His Moroccan Majesty, in a conversation on the subject, stated publicly that Spain would give him a warship to take these two persons to Constantinople. I do not know if this story is true, but we shall soon know for sure because if the king of Morocco thinks such a thing he usually writes to me in advance. ${ }^{142}$

González Salmón did not know the exact nature of their mission, but he assumed it was an attempt to have Spain and Portugal pledge to block the Russian war squadron from crossing the Strait of Gibraltar, and also to mediate among Morocco, Algiers, Tripoli, and Spain. This was indeed the case. ${ }^{143}$ When the Turks had completed their mission the sultan asked the Spanish priest at the Moroccan court to convey to the consul his desire to have two Spanish warships return the ambassador and the envoy to Istanbul, together with a Moroccan alcaide, their respective retinues, and a number of gifts. The sultan hoped that on the return journey one of the ships could take aboard his son-inlaw Muley Abdelmeleck, who was in Damascus "on his way back from making the pilgrimage to Mecca."144

140 This might be the same man as Asmet Asemi Saquir Fas, who figures in the account of a journey that a Spanish war frigate made to the Ottoman capital in 1788: Moreno, Viage, Appendix, xxv-xxvi.

141 J.M. González Salmón to Count Floridablanca, Tangier, 8, 9, and 26 June 1787, A HN, Estado, leg. 4319 .

142 "[T] anto dicho Enviado Turco, como el Embaxador de la misma Nacion que bá de camino à Marruecos volverán à Esta para embarcarse por este Puerto, y se dice que S.M.M. haciendo conversación sobre esto profirió públicamente que la España le daría un Buque de Guerra para llevar á dichos dos sujetos a Constantinopla. No se que verdad tenga esta noticia, pero en brebe se sabra con certeza por que si el Rey de Marruecos lo piensa asy, es regular me lo escriba con alguna anticipación": J.M. González Salmón to Count Floridablanca, Tangier, 15 September 1787, AHN, Estado, leg. 4319.

143 J.M. González Salmón to Count Floridablanca, 8 June and 6 and 17 August 1787, AHN, Estado, leg. 4319.

144 Letter from Father Cristóbal Ríos to J.M. González Salmón, 2 October 1787. J.M. González Salmón to Count Floridablanca, Tangier, 26 October and 10 and 27 November 1787. The 
Spanish authorities expressed their displeasure to Sidi Muhammad Ben Abdallah over Istanbul's policy, which opposed the entrance of foreign ships into the Bosporus; they refused to allow the Turks to travel to the court in Madrid. ${ }^{145}$ In February 1788 the Turks embarked in the Spanish war frigate Santa Cecilia. The Ottoman ambassador, the envoy ("a Turkish minister who was in his domains") and the Moroccan Tahir Fannis, with their respective retinues, made a total of seventy-four people. ${ }^{146}$ The frigate sailed for Cartagena where it was joined by the war brigantine Ardilla, and they proceeded from there to Constantinople. ${ }^{147}$

\subsubsection{Ahmed Ben Ali Khudja, Ambassador from Tripoli (1783-1787)}

In 1783 the Regency of Tripoli sent an ambassador, Ahmed Khudja, ${ }^{148}$ to Morocco in order to negotiate with Spain using the sultan as mediator. ${ }^{149}$ He played only a modest role, and after a long stay in Morocco and having requested unsuccessfully to visit the Spanish court, he began the return journey to Tripoli in October 1785 . The sultan allowed him to load six ships with wheat on the

sultan urged the Spanish ships to arrive in Tangier "soon, soon": translated letter from the sultan to J.M. González Salmón, 4 October 1787, AHN, Estado, leg. 4319.

145 Draft from San Lorenzo [El Escorial] to J.M. González Salmón, 7 September 1787, AHN, Estado, leg. 4319 .

146 On the preparations for their return see J.M. González Salmón to Count Floridablanca, Tangier, 9, 12, and 27 November 1787. Draft from San Lorenzo de El Escorial to J.M. González Salmón, 23 November 1787. The frigate Santa Cecilia sailed from Tangier for Cartagena on 16 February: J.M. González Salmón to Count Floridablanca, Tangier, 18 February 1788, AHN, Estado, leg. 4319. See also Moreno, Viage, Appendix, xxv-xxvi.

147 On their arrival in Istanbul the Turkish and Moroccan ambassadors and envoys wrote to the Spanish court "expressing their complete satisfaction with, and praise for, the extraordinarily fine treatment they received during their passage in those ships from Tangier to Constantinople": San Ildefonso to J.M. González Salmón, 23 September 1788. The Spanish consul in Tangier was pleased with the Moroccan envoy's attitude, "so that we can be sure he will make a good report to the king his master": J.M. González Salmón to Count Floridablanca, 15 October 1788, AHN, Estado, leg. 4321.

148 Also called Jamet Jogga and Jame Ben Aly Jacha. Arribas Palau, "Un litige"; his study is based on legajos 4319, 4352, 4692, and 4801 of the Estado section of the AHN.

149 He arrived in Tangier on a Ragusan ship: J.M. González Salmón to Count Floridablanca, 12 December 1783. Fray Espinar, who directed the Spanish hospice in Meknes, reported that he approached the Moroccan sultan as a mediator in peace negotiations with Spain: Espinar to J.M. González Salmón, Marrakesh, 13 February 1784. In August he told the sultan that he wished to cross to Spain:J.M. González Salmón to Count Floridablanca, 20 August 1784, AHN, Estado, leg. 4317. In June 1784 the Secretariat of State reported to the Spanish consul in Tangier that two letters had been sent about the Tripolitan, with a reminder "to try to prevent this man from coming to Spain": Count Floridablanca to J.M. González Salmón, 8 August 1784, AHN, Estado, leg. 4316. 
condition that he take them to Tripoli to alleviate a shortage of grain there. In December 1786 the sultan demanded that the Spanish consul in Tangier detain the ambassador "wherever he may be," either peacefully or by force, ${ }^{150}$ because he had learned that Khudja had sold the grain in Cartagena and Málaga, where he was then residing:

He is in Málaga involved in lawsuits about wheat that he loaded in Dar alBeida, and His Majesty is angry at this person's conduct; because having granted him permission to export grain from the port of Dar al-Beida free of all duties, on the express condition that it be conveyed to Tripoli to ease the shortage that was being suffered there, he has learned that of all the grain that this Moor loaded none has gone to Tripoli, and that he sold it to Spanish and Portuguese merchants. ${ }^{151}$

The consul decided that since the Tripolitan was not a Moroccan subject he could not force him to sail to Morocco, nor could he detain him in Spain; but he did write to the Captain General of the coast of Granada, who had Málaga in his jurisdiction, asking him to prevent the envoy from leaving Spain until he received instructions from his superiors. The Secretariat of State, on being informed of the matter, declared that "we cannot fail in hospitality to this ambassador nor force him, but His Majesty will join his pleas to those of the King of Morocco, if the latter wishes, that he be punished in Tripoli."152

Pressure on the Spanish consul increased; he reported that the sultan's brother-in-law and secretary, al-Zuwayin (Essuin), "in his crude way of thinking imagines that the king his master rules in all the world." At the same time the Moroccans, having informed the Bey of Tripoli of the affair, asked that Khudja

150 Translation of a letter from the sultan to J.M. González Salmón, 26 November 1786, AHN, Estado, leg. 4319 .

151 “...[S]e halla en Malaga con algunos litigios sobre Trigos qe embarcó por Darbeyda, y S.M. está resentido de la conducta de este sugeto por que haviendole hecho la gracia de que extragese Granos por dicho Puerto de Darbeyda libre de todo Derecho con la presisa condición de que se havian de conducir a Tripoly, para socorrer la carestía que allí se padecía, ha sabido que todo el Grano que este Moro embarcó, ninguno ha ido a Tripoly, y que lo vendió a Comerciantes Españoles, y Portugueses." The sultan also wanted the captains of the four ships that had loaded the wheat to be surrendered to him: J.M. González Salmón to Count Floridablanca, 19 December 1786, AHN, Estado, 4319.

152 J.M. González Salmón, Tangier, to Count Floridablanca, 19 December 1786. In another letter he remarks that the king did not wish to act violently toward the ambassador, and perhaps the sultan "may desist from his effort, if he realizes how unlikely it is that the Tripolitan or the captains who transported the wheat will go there": J.M. González Salmón, Tangier, to Count Floridablanca, 12 March 1786, AHN, Estado, leg. 4319. 
"be forbidden to leave Málaga until the Bey of Tripoli has dealt with him."153 The Granadan officer informed Khudja that the Moroccan sultan wanted him in Morocco, but Khudja "excused himself, alleging that he had interesting affairs that prevented him from obeying the will of this monarch." He did promise "on his word of honor," however, not to leave Málaga. ${ }^{154}$ In January 1787 the Secretariat of State repeated to the consul that he must tell the secretaries Muhammad b. al-Arbi Qaddus Effendi and Essuin once more that the ambassador could not be detained nor forced to go to Morocco, and the only solution would be for the Bey of Tripoli to punish him. ${ }^{155}$ But the sultan continued to insist that the Tripolitan be turned over to him:

If he is willing to come, you will put him on a ship and send him to Tangier; and if he is unwilling, let him be put in chains and sent to Tangier by force and against his will, for that is what the Bey of Tripoli has written to us. ${ }^{156}$

González Salmón saw it "very unlikely that he will want to come to these domains of his own accord," though he did not think that the affair would lead to hostility between the courts of Spain and Morocco. ${ }^{157}$ His judgment was correct: by July of that year the sultan, at the urging of the Bey of Tripoli, had pardoned Khudja, requesting that Spanish courts rule on the case between the Tripolitan and his Christian partner so that "each one shall be given what rightfully belongs to him so that he may soon conclude his business and go to Tripoli."158 The sultan's wish coincided with that of the Bey of Tripoli, who wrote to the Spanish sovereign asking for a quick resolution of the matter and a just decision for Khudja.

The ambassador's contacts must have been excellent, since he managed to interest the monarch in his case and to have Floridablanca, the Secretary of

\footnotetext{
153 J.M. González Salmón to Count Floridablanca, 29 December 1786, AHN, Estado, leg. 4319.

154 J.M. González Salmón to Count Floridablanca, 29 December 1786, AHN, Estado, leg. 4319.

155 J.M. González Salmón to Count Floridablanca, 16 January 1787, AHN, Estado, leg. 4319.

${ }_{15} 6$ "Si quiere venir, vosotros lo embarcareis y lo embiareis a Tanger, y si no quiere venir ponerlo en grillos y que se mande a Tanger por fuerza y contra su voluntad, que assy nos lo ha escrito el Bey de Trípoli": translation of the letter from the Moroccan sultan dated 24 January 1787 , AHN, Estado, 4319.

157 Two letters on the same date: J.M. González Salmón to Count Floridablanca, Tangier, 9 February 1787, AHN, Estado, leg. 4319.

$15^{8}$ J.M. González Salmón to Count Floridablanca, Tangier, 19 June and 24July 1787; translated letter from the sultan to J.M. González Salmón, 28 July 1787, AHN, Estado, leg 4319.
} 
State, intervene in it while delegating some of it to the maritime consulate in Málaga. Khudja wrote to the Moroccan sultan lamenting the events and his own ill luck: "For a year I have been in litigation without any justification on their part, and the abuses and injustices continue." In his closing words he cleverly flattered the sultan:

I have been shamed before God, my sovereign, and the Prophet Our Lord Mohammed (may he be praised!). Let not my sovereign allow them to mock me and my Regency, for what is done to me is as if it were done to my nation. ${ }^{159}$

It was true that he had sold the wheat in Cádiz, Cartagena, and Málaga. He acknowledged in his letter that he had left Tripoli without any money, and that therefore two merchants settled in Málaga, Juan the Turk and Esteban Descovich, had lent him the funds for buying the wheat, chartering ships, and paying for his quarantine and other expenses, and he could repay them only by selling the wheat. The Swiss consul, who had received Khudja into his home, was also implicated. The maritime and terrestrial consul in Málaga determined that half the proceeds should be distributed to Juan the Turk and Descovich, with Khudja retaining the other half, and the affair was finally settled in October 1787 .

\subsection{Muslim Envoys}

As we stated at the beginnng of this chapter, many envoys or emissaries left North Africa on assignments to Spanish ports or planning a brief stop in them. ${ }^{160}$ It can be difficult to establish a clear difference between true ambassadors and emissaries, and between the latter and tradesmen entrusted with some errand, often to purchase certain products for their sovereigns. In this section I shall include those who went on to third countries but made stops in

159 "Yo estoy en la vergüenza de Dios, de mi Amo, y del profeta Nuestro Señor Mahomet que sea alabado, y no permita mi Amo que se burlen de mi y de mi Regencia, pues lo que me suzeda a mi es lo mismo que si fuera a mi Nacion." He opened the letter by calling the sultan "the exalted and powerful king who lifts the banner of the Mohammedan religion, the refuge of one and all, defender of the Faith, protector of the poor": Khudja to the sultan of Morocco, Málaga, 10 January 1787, AHN, Estado, leg. 4319.

160 There were probably many more than those we describe here. 
Spanish ports or sailed in Spanish ships. Some of these men were on pilgrimage to Mecca, a circumstance the sultan used as a means of sending gifts to the Ottoman caliph. Most of our examples, naturally enough, involve Moroccans, since those are the most abundantly documented.

\subsubsection{Moroccan Envoys}

The sultan of Morocco sent many envoys and commissioners to different Spanish ports, especially to Cádiz; usually he charged them with acquiring luxury consumer items such as carriages, windows, furniture, gold vessels, watches, chocolate, and textiles, among others. By all accounts the individuals who carried out these commissions caused few problems and were not involved in unpleasant incidents - at least, so far as we can tell from our sources. But a minority of these agents created real difficulties during their stays of varying lengths in Spain, as we shall see further on.

\subsubsection{Admiral al-Mansur (1767-1768)}

One of these conflicts served as the prototype for others that came later. A Moroccan corsair frigate, the Mahona, in which Admiral al-Mansur was sailing under Captain Mohamed "Porto Mahón," entered the port of Cartagena for repairs after having suffered damage. Mansur accused the shipyard's personnel of delaying the repairs and treating him with disrespect and even abuse; he therefore decided to travel to the court in Madrid to complain to the king in person, ask his help in repairing the ship, and denounce the authorities in Cartagena. On arriving in the capital on 30 December he met the Marquis of Grimaldi, then Secretary of State, and asked him to convey his appeal to the monarch. His stay must have been brief, because by early February 1768 he was in Tarifa on his way back to Morocco. On 22 January Spain's consul general in Larache, Tomás Bremond, had already received two letters from Mansur to the sultan and had sent them to Madrid to be translated by a trusted interpreter: they revealed that Mansur was actually a French renegade who "cannot write Arabic and understands it even less, and as an apostate could cause us no end of trouble." In the letters Mansur described his interview with Grimaldi while complaining of his ill-treatment in Cartagena and the high price of food in Spain. We do not know how the affair ended, but the sultan did express his thanks for the repair of the frigate. ${ }^{161}$

161 Arribas Palau, "La estancia en España del almirante al-Mansur"; Posac Mon, "El alcaide Monzor." 


\subsubsection{Hach Abdelmagid Ben Zerak (1774)}

Al-Gazzal, the ambassador who had signed the peace treaty of 1767 and was now the sultan's secretary, wrote to the Marquis of Grimaldi, the Secretary of State, in June 1774. The letter recommended the alcaide Sidi Hach Abdelmagid Ben Zerak, ${ }^{162}$ who was being sent to Madrid to collect the one hundred Moroccan slaves that Charles III was presenting to the Moroccan sovereign as a gift; they had been captured out of Algerian corsair ships. While noting that Ben Zerak did not hold the rank of ambassador, al-Gazzal said,

I beg you to attend him until he returns satisfied with the exercise of his mission, as I do not doubt will also happen with Alcayde Abdenzit. ... I advise you that Elzerac is not an ambassador, and the king my master sends him so that you may know the man who brought theAlgerian slaves and see how well he treated them along the way. ${ }^{163}$

Abdelmagid Ben Zerak presented gifts to the Spanish monarch during his stay in Madrid, then traveled to Cartagena in October 1774. He took charge of the Moroccan slaves and several Algerians who were unable to work, and remained awaiting the gifts that Charles III was sending to Sultan Muhammad Ben Abdallah:

On the afternoon of this day [ 14 October] the Moroccan alcaide, Captain Abd-el Cid-el Cerut, arrived with a large contingent proceeding from Madrid, where he had been sent by his sovereign to take certain gifts to His Majesty. In this city he lodged in the house of the deceased commandant general of the Department, Don Carlos Robbio. He remained in Cartagena until he received the gifts that the king was sending to the sultan of Morocco, and as he was departing he was given one hundred Moroccan

162 It is often difficult to identify individuals when their names are transliterated so differently in contemporary documents. This man appears as Abdelmagid Ben Zerak, Sidi Hach Abt elmayid, Abdencit Elcerac, Abd-el Cid-el Cerut, Abd del Mich el Sarc, and other variants. While there is doubt about whether the reference is always to the same person, I have chosen to call him Abdelmagid Ben Zerak.

163 "Yo te suplico que lo atiendas hasta que buelba gustoso al exercicio de su empleo, lo que no dudo, que también suceda con el alcayde de Abdenzit [...] Te advierto que el citado Elzerac no es ningun Embajador, y solamente si lo embia el Rey mi amo para que veas el hombre que ha traido los Esclavos de Argel, por lo bien que los cuidó en el camino." Letter from al-Gazzal, secretary to the Moroccan emperor Sidi Mohammed Ben Abdalla, to the Spanish Secretary of State Marquis of Grimaldi, whom he addresses as "my dear friend": Salé, 13 June 1774, AHN, Estado, leg. 4312. 
slaves and the aged or injured ones from Algiers. And although before his departure news had arrived of Morocco's declaration of war against Spain, by order of the king the Moroccan ambassador was treated with the greatest kindness and attention. ${ }^{164}$

At that time he was strongly inclined to defend Spanish interests, as the Spanish friar José Boltas later recalled:

This Moor, whom I met and dealt with when he was ambassador in Madrid, seemed to me very positively inclined for when the occasion should arise. ${ }^{165}$

But the moment was not propitious: growing tension between the new Alawite ruler Muley al-Yazid and the Spanish crown led to the attack by Moroccan troops on Melilla and El Peñón de Alhucemas. Spain responded with a royal decree that contained a declaration of war.

The treaty of 1767 provided that, in the event of war, there would be a sixmonth period during which citizens of each country could be repatriated. ${ }^{166}$ The sultan argued that he was waging war by land, against the Spanish presidios, but not by sea (and he gave the appropriate orders to the governors of his port cities, which they obeyed). But he refused to allow Spanish residents in his domains to be repatriated until his envoy and the slaves freed from Cartagena had arrived home; Spain countered by blocking their return to Morocco until Spaniards had been embarked from North African ports. The slaves were sent to Algeciras, where they waited until it was confirmed that all Spaniards residing in Morocco had left that country without difficulty. ${ }^{167}$ The Secretariat

164 "En la tarde de este dia llega a Cartagena el alcaide de Marruecos Abd-el Cid-el Cerut arraes, con una numerosa comitiva, procedente de Madrid, a donde fue enviado por su soberano para traer ciertos regalos á S.M., alojándose en esta ciudad en la casa que ocupó el finado comandante general del Departamento D. Carlos Robbio. Permaneció en Cartagena hasta que recibió los regalos que el rey enviaba al sultán de Marruecos, y á su marcha le fueron entregados 100 moros esclavos marroquíes y los inútiles de Argel; y aunque antes de partir había llegado la noticia de haber declarado Marruecos la guerra a España, por orden del rey se trató al embajador marroquí con el mayor esmero y atenciones": Martínez Rizo, Fechas y fechos, 181.

165 José Boltas to Count Floridablanca, Meknes, 27 April 1783, AHN, Estado, leg. 4313.

166 Spain's vice consul in Larache, Francisco Pacheco, wrote in French to the sultan's secretary Samuel Sumbel to remind him of Article 27 of the treaty, which called for mutual repatriation without "any insult or prejudice": Larache, undated, AHN, Estado, leg. 4312.

167 Francisco Pacheco told the Secretary of State that the governor of Tangier had orders to let the Spaniards go "as soon as the ships of the king my master that should carry Alcayde Abenzit Elzerac, his retinue, the Moorish slaves, and gifts arrive at this port": Pacheco 
of State told Spain's vice consul in Larache, Jorge Patissiati, to inform the city's governor that Abdelmagid, his large retinue, and the slaves would be conveyed there on warships as long as Spaniards were not prevented from leaving port. ${ }^{168}$ In the end the matter was settled peacefully. ${ }^{169}$

Abdelmagid, aware of the existing state of war and the uncertainty of the moment, wrote to the Spanish authorities to thank them for the treatment he had received:

I cannot fail to express to His Majesty how thankful I am, with all my retinue, for the notable favors we owe to him, and I wish Your Excellency to convey to him how deeply I regret the (apparent) breach between my master and your sovereign, so unexpected and without a known reason. I wish to assure you that this change is not a natural part of the intense affection that he has always shown toward His Majesty and his vassals, which makes me believe that he has been badly advised, perhaps by some nation that is opposed to the tranquillity of both kingdoms. But ... I believe that he will alter his declaration in such terms that far from calling for war he will call for peace, giving His Majesty the greatest satisfaction. ${ }^{170}$

to Marquis of Grimaldi, Tangier, 7 November 1774, and a second letter of 15 November 1774: AHN, Estado, leg. 4312.

168 Draft of a letter sent from San Lorenzo de El Escorial, 1 November 1774, to Tomás Bremond, AHN, Estado, leg. 4312.

169 Pacheco asked the Secretary of State to "make those people, and even the king of Morocco, understand that if he does not allow free exit to the Spaniards they will not receive the free Moors, the slaves, or the gifts": F. Pacheco to Marquis of Grimaldi, Tangier, 3o November 1774. There was a second letter on the same subject, 12 December 1774.

170 " $[\mathrm{N}]$ o puedo por menos dexar de manifestar a S.M. lo agradecido que le quedo, como toda mi comitiva por los singulares favores, que le tenemos merecidos á quien asimismo estimare haga V.E. presente lo sensible, que me es el rompimiento (que parece) há hecho mi Amo con este Soverano tan impensadamente y sin algun conocido motivo, por que no dexo de advertir, que esta Mutacion no es natural en el Yntenso cariño que siempre ha manifestado á S.M. y vasallos, por lo que debo creer, ha sido mal aconsejado tal bez de nación opuesta a la tranquilidad de las dos Coronas; Pero ...creo mudará su dictamen en tales términos, que lexos de la guerra, clamará la Paz, llenando á S.M. de las mayores Satisfacciones." Abdelmagid accused the consul T. Bremond for "his thinking which is opposed to our own in everything, and for having had some disagreements with both the father and the son": letter signed in Arabic from Sid Hach Abdelmagid to Marquis of Grimaldi, Cartagena, 1 November 1774, AHN, Estado, leg. 4312 . 
However, he made the mistake of writing three letters to the governor of Tangier to be forwarded to the sultan and conveyed by the Spanish royal navy. ${ }^{171}$ The Secretariat of State asked the interpreter and librarian Miguel Casiri to translate them and determine if they referred to "the outbreak of war between Spain and Morocco."172 The letters revealed that Abdelmagid was exasperated by the tension of waiting aboard a warship off Algeciras without being allowed to land; they were "full of complaints and oaths because of his long delay in Algeciras with his retinue, always at sea without a chance to set foot on land."173 But he seemed much more annoyed at not being received as an ambassador - though he was not entitled to that rank - and not having been offered the sums and gifts that al-Gazzal had received in his day. The translator observed that Abdenzit used such "coarse and indecent" terms and "indecorous expressions" that he did not dare to translate them literally:

Abdelmagid writes a letter to the king of Morocco that, because it is written barbarously and without any method or spelling and with indecent expressions against the sacred person of our lord king, ... I do not translate as Your Excellency commands me to do. Its content is no more than his violent detention in Madrid.... He writes other letters along these lines to several friends saying that he has rejected the offers that the king of Spain made him, saying that he needed nothing while he enjoyed the favor of his sovereign. He has complained that he did not receive the treatment and money that they gave to Ambassador al-Gazzal. In these letters he does not speak of war nor show gratitude for the favors, benefits, and graces that he has received, though undeserving. ... Every time he names [the king] in his letters he adds, "May God confound him!"."17

171 The Secretariat of State told the Spanish consul in Tangier that the commander of the squadron in the Strait had sent him "some papers that Alcaide Abdencit Elcerac had given him for the governor of Tangier; and since in the present circumstances I thought I should intercept them, I had them opened": draft from San Lorenzo de El Escorial, 1 November 1774, AHN, Estado, leg. 4312. Since 1767 most of Morocco's international correspondence had been handled by the Spanish postal system.

172 "I send you the attached letters in Arabic so that you can tell me the substance of their contents and translate any of them that deals with an important matter, especially if it concerns the outbreak of war between Spain and Morocco": draft to Miguel Casiri dated 28 October 1774 in San Lorenzo de El Escorial, AHN, Estado, leg. 4312.

173 Miguel Casiri to Marquis of Grimaldi, 24 November 1774, AHN, Estado, leg. 4312.

174 "Abdelmagid escribe una carta al Rey de Marruecos, la qual por ser bárbaramente escrita sin método, ni orthografia y con expresiones indecentes contra la sagrada persona del Rey Nro.Señor..., no la traduzco como me lo manda V.E. Su contenido se reduce a su violenta detención en Madrid ... de este tenor escribe otras cartas a varios amigos en que les dice 
Tomás Bremond, the consul general in Morocco, lamented that their guest should speak so indecorously of the Spanish king after he had (mistakenly) been well treated:

[I regret] the treatment he was given and the many signs of respect and honors made to him even though the rank he held did not deserve them, and in spite of His Majesty's generosity in restoring the slaves and in the gifts destined for the [king] of Morocco. I will write in this vein to that prince and explain the high distinction that was offered to the Alcayde, and will tell him that he unquestionably burst out with terms that were indecorous and shameless toward the sacred person of our sovereign. ${ }^{175}$

Such behavior came as no surprise to the consul, who had formed a poor opinion of the Moroccan:

Nothing of what Alcayde Abdencit has done has been new to me, because I knew his bad manner of behaving (I think I recall telling Your Excellency about it). And I always felt that in return for the infinite favors done to him he would respond in just this way. ${ }^{176}$

Several letters exchanged between the consulate in Tangier, the Secretariat of State, and other Spanish bureaucrats spoke of the "coarse and indecent terms"

que ha despreciado las ofertas que le ha hecho el Rey de España, diciéndole que nada necesitaba, teniendo la gracia de su Rey \& quando este se ha quejado porque no le dieron el tratamiento y dineros que le dieron al Embaxador Algazeli. En estas Cartas no habla de guerra, ni se muestra agradecido de los favores, beneficios y gracias que sin merito ha recibido..., que cada vez [que] le nombra [al rey] en sus Cartas, añade Dios le pierda [underlining in original]". Miguel Casiri to Marquis of Grimaldi, Madrid, 30 November 1774. Another letter is dated 29 October 1774, AHN, Estado, leg. 4312.

175 “...del trato que se le havia dado, siendo [no] pocos los obsequios y demostraciones, que se le han hecho sin merecerlo el carácter con que venia, y generosidad de S.M. en la restitución de esclavos, como en los regalos, que se han destinado ál de Marruecos, en cuyo supuesto escriviré a aquel Principe, exponiéndole la suma distinción con que se ha tratado á dho Alcayde, y asi mismo le manifestaré constar de positivo hauer prorrumpido en términos indecorosos, y del mayor descaro contra la sagrada Persona de nuestro soberano": T. Bremond to Marquis of Grimaldi, Cartagena, 5 November 1774. A HN, Estado, leg. 4312.

176 "Nada de quanto ha hecho el Alcayde Abdencit me ha causado novedad, pues sabiendo yo su mal modo de obrar (que según hago memoria lo notizie a V.E.) siempre consentí, que en pago que los infinitos favores que se le han hecho, havia de dar los agradecimientos en los términos que lo ha executado": Tomás Bremond, Spanish consul in Larache, to Marquis of Grimaldi, 12 November 1774, AHN, Estado, leg. 4312. 
that Abdelmagid applied to "the sacred person of our sovereign." The correspondents also agreed that his complaints were unfounded, since he had been treated very well, "though undeserving." Therefore the consul was instructed to tell the sultan about

the high distinction with which Abdencit has been treated here, His Majesty's liberality in sending him the slaves, and the gifts that His Majesty offers him in spite of the rupture of the friendship that existed between the two sovereigns; [and the consul should] relate in detail the gifts presented to Alcaide Abdencit and his retinue.

Bremond should also refer to the "indecorous and shameless" language that Abdelmagid had used about the king. But he must not reveal how the Spaniards learned the contents of the envoy's letters, "maintaining silence about our having learned of this through letters from the Moor himself, and the fact that they were opened."177

The letters from the Spanish to the Moroccan court were never given to Abdelmagid, ${ }^{178}$ but despite his actions Spain's response was the same we have seen earlier: to try to lessen the punishment that the sultan would probably impose on him, both to soften Abdelmagid's hostility to Spaniards and to win him over as a possible ally in the sultan's court. That was why, once again, the king of Spain let the sultan know that he would not punish the envoy's behavior as it deserved:

He has not wished to have him punished as his rashness merited, both because His Majesty holds Abdencit's lowly person in contempt, and in order to give a fresh example of his merciful heart; and so that the king of Morocco may understand, by this small show of magnanimity, how noble

177 "la suma distinción con que se ha tratado aquí á Abdencit, la liveralidad de S.M. con embiarle los Esclavos, y los Presentes que S.M. le dirige, no obstante aberse quebrantado la amistad que susbsistia entre ambos Soberanos, refiriendo también por menor los Regalos hechos al Alcaide Abdencit, y á su comitiva ... bien que callando la especie de saberse esto por cartas del mismo Moro, y la circunstancia de habérsele abierto": draft for Tomás Bremond dated 1 November 1774, San Lorenzo de El Escorial, AHN, Estado, leg. 4312.

${ }_{17}$ The Spanish letters for the Moroccan sultan would be delivered directly to the governor of Tangier, "because it is not decent that they should go by [Abdelmagid's] hand, nor can we trust him in view of the falsehoods he proclaims": San Lorenzo el Real to T. Bremond, 1 November 1774. San Lorenzo to José de Roxas, commander of the squadron, 1 November 1774. J. de Roxas to Marquis of Grimaldi, Cartagena, 25 October 1774, AHN, Estado, leg. 4312. 
and generous is the prince with whom he once made peace and whom he has failed by breaking the solemn and sacred pact they had agreed on. ${ }^{179}$

When Abdelmagid was finally able to leave Algeciras for his country, Tomás Bremond received four letters that he had left with Spaniards to be delivered to his friends in Morocco. The consul sent them to Madrid where Casiri translated them, but they contained nothing of interest. ${ }^{180}$

\subsubsection{Sidi Mahamet (1780)}

Two ship captains, Cador Saibanu and Adad, reached Almuñécar in August 1780, bringing an envoy from the sultan:

On the first of this month a caravel docked in the port of Almunécar, coming from Tetouan under the two Moroccan navy captains Cador Saibanu and Adad, conveying an envoy from that sovereign named Cid Majamet. It seems he will meet privately with the governor of Melilla, and on his way there will hand a letter to the commandant of that region. Later he is to continue to Algiers on another commission whose nature we have not been able to determine in spite of all our efforts.

The Secretariat of State asked to be kept fully informed of the matter. ${ }^{181}$

\subsubsection{Sidi Mahamet Sarjony (1777-1778)}

The sultan of Morocco sent two talbes, Sidi Mahamet Sarjony and Sidi Abdelmevy Ben-Guaseduc, ${ }^{182}$ to convey Muslim slaves rescued from Malta to the

179 "[N]o ha querido hazerle castigar según merecia su osadia, asi por el desprecio que haze S.M. de la infima persona de Abdencit, como para dar un nuebo exemplo de su piadoso corazon, y para que por este leve rasgo de magnanimidad comprehenda el mismo Rey de Marruecos, quan noble y generoso es el Principe con quien hizo pazes, y á quien ha faltado quebrantando el solemne y religioso Pacto ajustado": San Lorenzo el Real to T. Bremond, 1 November 1774. San Lorenzo to José de Roxas, commander of the squadron, 1 November 1774, AHN, Estado, leg. 4312.

180 Miguel Casiri to Grimaldi, 19 December 1774. T. Bremond to Grimaldi, 3o December 1774, AHN, Estado, leg. 4312.

181 "El $1^{\circ}$ de este mes arrivaron al puerto de Almuñecar en un carabo procedente de Tetuán los dos capitanes de marina marroquíes Cador Saibanu y Adad con un embiado de ese Soberano llamado Cid Majamet que parece va a tratar reservadamente con el Gobernador de Melilla, entregando de camino una carta al Alcayde de aquel Campo, y que luego debe pasar a Argel con otro encargo, cuyo objeto no se ha podido averiguar por mas que se ha procurado con industria": draft letter from San Ildefonso to Boltas, 15 August 1780, AHN, Estado, leg. 4313 .

182 Sarjony also appears as Esanjony, Esorjony, Sorjoni, and even Rajoni. 
Ottoman Empire. ${ }^{183}$ The Spanish consul in Tangier chartered the ship that took them from there to Tarifa. They wanted take eight servants, a number that the consul managed to reduce to six: "no matter how often I told them that so many people were useless it was impossible to lessen their number, for they even wanted to take two more men."184

Sarjony, on his arrival in Palma de Mallorca by way of Tunis, claimed to be the sultan's ambassador. Though his only credential was a letter from Manuel Ventura Buzarán, the Spanish commercial agent in the Regency, he convinced the local authorities to charter him a ship at the Royal Treasury's expense to take him to Morocco. The Spanish consul in Tangier told the Secretary of State to warn the local commanders and governors along the coast that

if the Moroccan Moors do not bear any particular recommendation, they should be treated with no more distinction than what is required by the good reciprocity and friendship that exist between our two nations; for these people abuse our generosity.

He reported that Sarjony had also required his ship to make a stop in Ceuta, where "he was honored also." González Salmón felt that the "distinction" offered to Moroccans by Spanish authorities meant to reaffirm the friendship between the two countries, but noted that Moroccan subjects "cannot expect better treatment than what is given to our own citizens; they have no reason for complaint." And besides,

any special blandishment offered to the Moors is entirely useless, because the king of Morocco does not hear of it and they are incapable of being grateful for it - or it is rare that they appreciate it as it deserves - because they believe that any attention is owed to them by right. ${ }^{185}$

183 They were probably taken to Cartagena and Malta aboard the Spanish warship Miño: González Castrillo, El viaje de Gabriel Aristizábal, 20.

184 J.M. González Salmón to Count Floridablanca, Tangier, 8 August 1787, AHN, Estado, leg. 4319; the sultan had written to Charles III on 28 February 1787 informing him of the voyage.

185 “...que si los Moros Marroquies no lleban alguna recomendación particular, no se les haga otras distinciones que las que exige la buena correspondencia y amistad que hay entre las dos Naciones; porque estas gentes abusan de nuestra liberalidad .... [T] odo agasajo extraordinario que se haga a los moros, es enteramente perdido por que ny el Rey de Marruecos lo sabe, ny ellos son capaces de agradecerlo, ó es mui raro el que lo aprecia como corresponde, porque estan consentidos que qualesquiera atención se les debe de derecho." The ship captain in this case was Bartholomé Muret. J.M. González Salmón to Count Floridablanca, Tangier, 10 May 1788, AHN, Estado, leg. 4321. 
Sarjony also deceived the ship captain who took him to Tetouan, Bartholomé Mulet, promising him to arrange permission to ship wheat,

a promise as false as his claim to be the ambassador of the king of Morocco. For once on land he did nothing, nor could he, because this favor depends absolutely on the will of the sovereign, who is not very satisfied with this Moor's conduct: his assignment was to take the slaves not to Tunis but to Morea, which was the order the sovereign had given.

The consul also criticized Ventura Buzarán for his interference, though he realized that it came ultimately from the Bey of Tunis, who had advocated for the Moroccan. He instructed the governor of Palma that if, in the future,

some Moor appears there claiming to be an ambassador or other emissary of the king of Morocco, he not believe him unless the man can present some document, or a letter from me; because I have often experienced what Moroccans do when they go to Europe, and when they see that they are granted privileges they abuse the generosity and urbanity with which we treat them. ${ }^{186}$

The Secretariat of State told the consul that on account of Sarjony's deceptions in Tunis, Palma, and Ceuta, a circular had been sent to all the admirals of the Spanish coasts, the Balearic Islands, and the North African presidios, making them understand that

if any Moroccan Moors should present themselves without a letter from His Majesty's consul in Tangier explaining their circumstances and character, and the appropriate distinction they merit, they should receive only what is required by our respect and good harmony with the king

186 “...cuia promesa fue tan falsa como el ser el Embaxdor del Rey de Marruecos, pues luego que se vio en tierra nada hizo, ni es capaz, por que esta gracia pende absolutamente de la boluntad del Soberano, quien no se halla mui satisfecho de la conducta del mencionado Moro, por que su Comision no fue para conducir los Esclavos a Tunes, sino a Morea, que era la orden que llebaba de este Soberano. ... [Si] algun moro se le presente en esa y dice ser Embaxador, ú otro empleado del rey de Marruecos, no se le dé crédito sino lo hace constar por Documento, ó Carta mia, porque tengo repetidas experiencias de lo que hacen los Marroquies quando ban a Europa, y como ven que por alla se les franquean, abusan de la generosidad y urbanidad con que se les trata": J.M. González Salmón to Antonio Gutiérrez, governor of Palma de Mallorca, Tangier, 9 May 1788, AHN, Estado, leg. 4321. 
of Morocco. I therefore charge you with conveying this to that sovereign for his information, so that he will not be surprised if, in the absence of this condition, we fail here to offer the improper favors that his subjects demand everywhere they go. ${ }^{187}$

The Secretariat of State later informed the Spanish consul that Sarjony was in debt to a ship captain, José Ferrer, for the price of a Muslim slave whom he had bought and taken to Tetouan. The consul was to pursue Sarjony for the sum and, if he failed to pay it, to report his conduct to the sultan, "who surely does not wish his vassals to act so ungratefully, and the captain will receive his money in one way or another."188 We do not know the outcome of the affair, but in February 1789 the Moroccan minister promised that the debt would eventually be paid. ${ }^{189}$

\subsubsection{Atal Ba-Mar (1801)}

Atal Ba-Mar, who claimed to have been an ambassador of the deceased Muley Ben Abdallah, appeared in Madrid in January 1801: "First he was ambassador to Holland, second to England, and third, envoy to the court of Portugal." He presented a document to the Secretary of State that affirmed he had "always professed his love and loyalty to His Catholic Majesty." He recalled having supplied

187 “...a los moros marroquíes que se presenten sin carta del Consul de S.M. en Tanger en que exprese sus circunstancia, carácter y distinción particular que convenga hacerles, solo se les hagan las muy precisas de atención y buena harmonia con el Rey de Marruecos; y asi encargo a Vm lo haga presente á ese Soberano para su noticia y para que no extrañe que sin dicha circunstancia se falta aquí a las indiscretas condescendencias que sus súbditos exigen en todas partes a donde llegan": Aranjuez to J.M. González Salmón, June 1788, AHN, Estado, leg. 4321.

188 J.M. González Salmón to Count Floridablanca, Tarifa, 28 December 1788. In consequence the Spanish viceconsul in Tangier wrote to Minister Effendy, asking him to force Sarjony to pay his debt: if that did not happen "it will be suggested to His Moroccan Majesty that this money will be recovered in one way or another, and he does not like his vassals to behave with such dishonesty": Antonio González Salmón to Count Floridablanca, Tangier, 31 December 1788, AHN, Estado, leg. 4321.

189 Effendy assured the viceconsul that Sarjony would pay, so that "you do not need to write to my master about the matter, because after he returns from Tafilalt to this [city] he will pay what he owes without delay": translated letter from Effendy to A. González Salmón, 23 February 1789. The latter informed the Secretary of State and assured him that "I will not fail to remind the minister of the matter so that it may be resolved without any more delay": A. González Salmón to Count Floridablanca, Tangier, 28 February 1789, AHN, Estado, leg. 4321. 
the Spanish troops for more than two years with beef and mutton during the recent war with the French Republic; as a result he was given proper thanks in the royal palace of Aranjuez and had the honor of kissing His Majesty's royal hand, at the time when the "Prince of Peace" [Manuel Godoy] was in charge of the Secretariat of State and its ministry.

Ba-Mar reported having arrived in Majorca more than three months earlier in a chartered Moroccan ship. His cargo included, among other items, "fortyfour small bundles of muslin, cottons, kerchiefs, and other clothing that he had bought in the city of Faro in Portugal, all for 7,80o duros." The local health officer, Jorge Massias, with his brother and two other men, suggested selling the bundles for him and giving him the sale price; he agreed and the bundles, bearing Arabic labels, had been taken to a building in the countryside, probably belonging to a religious order. It was later discovered that "different pieces of clothing that were in the bundles" were missing. Six days later, customs officers seized the bundles and took them to their headquarters.

Atal Ba-Mar demanded the return of his bundles, but was told to appeal to the court because his goods were contraband. He explained in his report that his situation was pitiable, because "aside from what is told here he has suffered other misfortunes and losses that he does not recount so as not to weary Your Excellency's attention." He alleged having acted in good faith in the matter of the bundles, since "he never believed that the business was illicit, as was declared before the goods were seized." He requested intercession with the king or the Finance Minister, Miguel Cayetano Soler, for the return of the contents of his forty-four bundles or their equivalent in cash if they had been sold or auctioned. He also hoped "that this be settled with the greatest haste, since his king has told him to return to his country after concluding the business he was sent on and for which he left his kingdom."190

The Finance Minister was told that Ba-Mar had indeed been Morocco's ambassador to Holland, England, and Portugal, and had further "had commissions from this court that were approved." It was believed that he had been cheated

190 “[Había abastecido a las] Tropas Españolas cerca de dos años de Carnes Bacuna y lanar (carneros) durante la Guerra que se concluyó con la Republica Francesa: de cuias resultas se le dieron las devidas gracias en el real Sitio de Aranjuez, teniendo el honor de besar la real Mano a S.M. en tiempo que la secretaria de Estado y su Ministerio se hallaba al cargo del Exmo. Señor Príncipe de la Paz. ... "[Solicitó] que se le despache a la mayor brevedad, por estar avisado por su Rey, regrese a su Pais, después de tener concluidos los negocios de que fue encargado; con cuio motivo salió de su Reyno": Madrid, 17 January 1801. Signed in Arabic, AHN, Estado, leg. 5803, Exp. 20 (55). 
in the episode of the forty-four bundles ("they seduced him"). "In light of the circumstances that combine in this person, his importance in his own country, the posts he has held, and the fact that his sovereign is expecting him," he was presumably acting in good faith; therefore, although contraband was clearly involved, his appeal should be granted "with the greatest possible speed, since this Moor is called to new commissions by his sovereign":

In light of all this, though his goods are contraband he deserves to be treated with all possible favor. In informing Your Excellency of this I recommend this individual's situation and circumstances to you so that Your Excellency may explain it all to His Majesty. ${ }^{191}$

The Minister, Miguel Cayetano Soler, asked the supply officer of Majorca for further information and learned that there had indeed been a crime of smuggling. But he made no decision, leaving matters in the hands of the Secretary of State: "in the light of the Moor's situation and the need to placate his nation it may be necessary to adopt some other means; I beg Your Excellency to tell me the best course and to return the report to me."192 Soler was told that the king was referring the matter back to Majorca. ${ }^{193}$

At this point Ba-Mar presented a new report that complained of his situation: "because of this accusation he cannot return to his country for lack of means, after spending provoked by his good faith, and he should not be forced into ruin." He again recalled how many times he had supplied the Spanish army and navy "and may still do so." He was willing to modify his petition, asking that "out of kind generosity his needs be met by the return of what has

191 "En atención a lo referido y respecto de que dichos efectos, aunque sean de contrabando lo hacen acreedor a que se le trate con la benignidad que sea posible; participo a V.E. todo lo referido recomendándole la situación y circunstancias de dicho Yndividuo; para que se sirva V.E. hacerlo todo presente a S.M": unsigned draft, "To the Minister of Finance, the Palace, 28 January 1801," AHN, Estado, leg. 5803, Exp. 20 (55).

192 Miguel Cayetano Soler to Pedro Ceballos, Aranjuez, 21 March 1801, AHN, Estado, leg. 5803, Ex. 20 (55).

193 The king was aware of the report by the royal commissioner Antonio Alarcón Lozano, and ordered "that the case be returned to the sub-delegate with the petition by this Moor. The 85,144 reales and 6 maravedís de vellón should be returned by the persons who received them, and to the account of the case be added an interview with the Moor about the details of his petition that might help in judging it, then the account should be resubmitted with his statement. Separately the commander of the Customs should declare under oath who denounced [the Moor], and [that declaration] sent privately so as better to determine this matter": Aranjuez to Miguel Cayetano Soler, 26 March 1801, AHN, Estado, leg. 5803, Exp. 20 (55). 
gone to the treasury." A marginal note requests attention to "what this Moor has suffered through the deceits of employees in Majorca; and for the political reasons that I have explained to you, some favor should be done him in the amount that is owed to the Royal Treasury." ${ }^{194} \mathrm{~A}$ fresh directive to the Finance Minister asked him to bear in mind that "[Ba-Mar] has begged His Majesty - in view of his situation, his original good faith, and the large expenses his long residence has incurred - to do him the favor of returning to him the portion that went to the Royal Treasury and has to do with contraband."195

The matter was not yet settled in December 1801. Ba-Mar wrote yet another, virtually identical, appeal to the Secretary of State: it explained that the supply officer of the Kingdom of Majorca had agreed "that he be compensated with eight thousand duros as the value of the clothing he had sold to the said Mecias [sic], which was seized from him and, being confiscated as contraband, was sold by the Royal Treasury." Although the officer had seemed willing to obey the royal command,

he did it so slowly that months passed before he ordered any money paid. Finally after this time [Ba-Mar] was given only three thousand duros, with a promise to give him the rest from one day to the next, as well as the deductions that the royal order had also included; but up to now, after more than a year of waiting, he has been unable to recover the remainder of his interest, which puts him in the painful position of having to weary Your Majesty's sovereign attention once more.

Ba-Mar therefore beseeches the king to order the transfer of the full amount as soon as possible:

Tired of waiting for the gentleman supply officer of this region and Kingdom of Majorca to fulfill the royal order that Your Excellency knows of, that he pay me the eight thousand duros that were the value of my goods seized from José Mecias, an official of that kingdom, I have decided to approach the sovereign himself by means of Your Excellency with the report that I attach, requesting a renewed royal order so that, without an instant's delay, the Intendente pay the total of five thousand duros that have not yet been disbursed and the other expenses of my travels

\footnotetext{
194 Report by Ba-Mar, signed in Arabic, Aranjuez, 27 March 1801, AHN, Estado, leg. 5803, Exp. $20(55)$.

195 Aranjuez to Miguel Cayetano Soler, 27 March 1801, AHN, Estado, leg. 5803, Exp. 20 (55).
} 
and residence; hoping that Your Excellency will adopt this petition of a friendless foreigner who is your most humble servant.

A marginal note on the document reads: "If the order is genuine, let the treasury be informed that the matter be settled."196

\subsubsection{Other Muslim Envoys}

Aside from Moroccans, several envoys from other North African countries also passed through Spain, having landed there on a variety of missions.

In 1781 Sid Muley Ben-Oumar, a Turk, was in Morocco, having been sent from the caliph to the Moroccan sultan, and on his return journey he bore a letter from Muhammad Ben Abdallah, who was complaining to the caliph that Algiers was refusing to exchange captives with Spain. Consul González Salmón put Ben-Oumar aboard a Spanish fishing boat bound for Cádiz, where the consul from Ragusa would pay his passage for Constantinople. ${ }^{197}$

The Spanish consul in Tunis, Pedro Suchita, passed through Barcelona on his way to the court in Madrid in October 1787; he was escorting a representative of the Bey of Tunis, about whose mission we know very little. ${ }^{198}$

In 1800 Xamet Molotd or Mevlud, the Tunisian "son of our agent in Tetouan," contacted the Spanish ambassador in Lisbon; he was interested in the imperial brigantine La Dama Veneta, which had been seized on leaving Gibraltar and

196 “...[L]o hizo con tanta lentitud que pasaron meses antes que no le mandó entregar dinero alguno. Finalmente pasado este tiempo se le entregaron solo tres mil duros esperanzandole de un dia a otro de entregarle el resto y los menoscabos que assi mismo comprehendia la Rl. Orden: pero hasta ahora en mas de un año de detención no ha conseguido cobrar el resto de su interes poniéndole esto mismo en el dolorosa caso de cansar otra vez la soberana atención de V.M." "Cansado de esperar que el caballero Yntendente de este partido y Reyno de Mallorca cumplimentase la Real Orden que V.Ex $x^{a}$ tendrá presente para que dispussiesse pagarme ocho mil duros que valían mis generos que fueron aprehendidos a Jose Mecias Guardamar de dicho Reyno, he deliberado acordarlo al mismo Soberano por mano de V.Ex ${ }^{a}$ con el memorial que incluio solicitando repetida Real Orden para que sin demorar un instante realice el mismo Yntendente el total pago de cinco mil duros que faltan a entregarse, y los menoscabos de mis viajes y detenciones; espero que V.Exa que patrocine esta solicitud de un desvalido estrangero y su mas humilde servidor": the ambassador's statement from Palma de Mallorca, 3o December 1801. Signed in Arabic, AHN, Estado, leg. 5803 , Exp. 20 (55).

197 Juan Manuel González Salmón to Count Floridablanca, Tangier, 14 May 1781, AHN, Estado, leg. 4314.

198 Suchita asked that the quarantine period be reduced by a few days; he presented a petition dated 7 October 1787 explaining that he was on his way to the court with the representative. He was allowed a reduction of five days: IM HB, Fs, Serie I, leg. 18, fols. 148-50. Baron de Serrahi to Junta de Sanidad, 8 and 9 October 1787. 
carried the sum of ten thousand pesos. He claimed to be a representative of the Bey of Mascara bringing a letter from his master to the Spanish court, but an illness prevented him from traveling to Madrid. ${ }^{199}$

Two brothers, Casari Mahmet and Abdamar Casari, reached Barcelona in 1803 , presenting themselves as

sent by the Bey of Tunis to give a gift to the Emperor of Morocco. And for this commission they have no more than three months, while two servants and small amounts of silk and cotton have spent fifty days in quarantine and they do not yet release them. This causes me great harm, for in addition to these considerable expenses I cannot perform what my king has ordered, to give the gift within the aforementioned three months.

They asked that "the two servants together with the silk and cotton [be released] with all speed," since otherwise "I will have to leave those servants and other goods and depart to present my gift, which will cause me great harm."200

Sidi Mahamet, who must have claimed a certain status, arrived in Barcelona in a brigantine in 1807 with his family, servants, and baggage. An order was issued to shorten their quarantine: "in the knowledge that I reduce this quarantine out of mere consideration for the person involved, and it should not serve as a precedent in similar cases." 201

Once normal, peaceful relations had been established between Spain and Muslim countries, many Moroccan, Algerian, Tunisian, Tripolitan, and Ottoman ambassadors and envoys found themselves in Spain, whether on a diplomatic

199 Duke of Frías and Marquis of Villena to Mariano Luis de Urquijo, Lisbon, 7 and 16 October 1800, AHN, Estado, leg. 5806. We will return to this matter in Chap. 9, section 9.4.18.

200 “....E]nviados por el Bey de Tunis para entregar un regalo al Emperador de Marruecos y para dicha entrega no tienen mas tiempo que tres meses y habiendo pasado mas de $5^{\circ}$ dias que estan dos criados, y un poco de seda y algodón en la cuarentena aun no los despachan de lo se me sigue un perjuicio muy grande que amas de los gastos tan considerables como son no podre cumplir con lo que mi Rey me tiene mandado de hazer la entrega en el termino de los tres meses arriba expresados. ... me será preciso dejar los dichos criados y demas generos y marxar hazer mi entrega de lo se me seguirá un grande perjuicio": Report dated 17 June 1803, with two signatures, one stamped and one in Arabic script. The quarantine began on 28 May and should have ended on 6 July: IM HB, Fs, Serie I, leg. 24, fol. 61, 19 June 1803: FS, Serie v, leg. 13, fols. 258-59, 20 June 1803.

201 The visit of inspection was made on 16 June 1807: I M HB, FS, Serie I, leg. 28, fol. 102, Count of Santa Clara to Marquis of Valle Santoro, 14 June 1807. 
mission or as a simple pause in a sea voyage. In every case the Spanish authorities treated them in the manner they thought most proper. Though on rare occasions they expressed feelings of superiority, ${ }^{202}$ everything indicates that they received the Muslims respectfully and essentially as equals. I refer here to internal correspondence among Spain's Secretariat of State, consuls, governors of cities and regions, and so forth. This attitude is explained by the Spanish authorities' wish to cultivate trustworthy supporters in the North African and Ottoman courts.

The results of this policy varied. Especially in cases of ambassadors and envoys who were passing through temporarily, the demands they often made (seeking greater material and financial help, or claiming a higher rank than their real one) did not create the best atmosphere for forming strong alliances. The government resorted to the alternative - letting the Moroccan sultan and other rulers know about their subjects' bad behavior - only rarely, and when it did the Spanish consul general in Tangier was asked to seek clemency or, at worst, a mild punishment for the accused.

The Spanish were reluctant to facilitate visits by these envoys because of the high costs they entailed and because they might threaten the more or less cordial relations between Spain on the one hand and Morocco, Algiers, Tripoli, Tunis, and the Ottoman Empire on the other. While reasons of state took precedence over every other consideration, it is also true that the services and favors that Spain offered often strengthened ties of friendship that arose from mutual interests, increasing the influence of Spanish diplomacy in the Muslim Mediterranean.

202 It is naturally understood that when the consuls criticized these men or showed their disdain they were also trying to convey to their superiors the problems they were meeting in Morocco, Algiers, Tunis, Tripoli, and the Ottoman Empire: see Windler on the French consul in Tunis, La diplomatie. 